\title{
Performance of Composite Shear Walls Subjected to In-plane Cyclic Loading - A Numerical Parametric Study
}

\author{
Mojtaba Labibzadeh ${ }^{1 *}$, Anis Salehnia ${ }^{1}$, Khandaker M. A. Hossain² ${ }^{2}$ Deng-Hu Jing ${ }^{3}$ \\ ${ }^{1}$ Faculty of Civil Engineering and Architecture, Shahid Chamran University of Ahvaz, Ahvaz, Iran \\ 2 Department of Civil Engineering, Ryerson University, 350 Victoria Street, Toronto, ON, Canada M5B 2K3 \\ ${ }^{3}$ School of Civil Engineering, Southeast University, Nanjing, 211189, P. R. China \\ * Corresponding author, e-mail: labibzadeh_m@scu.ac.ir
}

Received: 29 July 2020, Accepted: 05 July 2021, Published online: 22 July 2021

\begin{abstract}
An RC shear wall (wall1), a composite shear wall composed of a single external steel plate connected to a concrete panel (wall2), a composite shear wall constructed from two external steel plates connected to an internal concrete panel (wall3) and finally a composite shear wall fabricated with a single internal steel plate embedded within a concrete panel (wall4) are considered in this study and their behavior are assessed and compared under the effect of an in-plane cyclic load. Variation of the three functions include shear load capacity, energy absorption and shear stiffness of the walls are evaluated numerically using the ABAQUS finite element software. The performance of numerical models is validated against to the experimental results. The effects of four parameters consisting of compressive strength of concrete, yield strength of steel plate, height-to-length ratio of the wall and the thickness of the steel plate are investigated on the above-mentioned functions. Obtained results show that the wall4 has the best performance among all four types of shear walls. For instance, the energy absorption capacity of the wall 4 is approximately two times greater than that of wall1 and wall2.
\end{abstract}

\section{Keywords}

composite shear wall, parametric study, lateral cyclic loads, shear load capacity, energy absorption, stiffness degradation, height-tolength ratio, plate thickness

\section{Introduction}

Extensive research works have been performed on studying the behavior of the composite shear walls in recent years [1-4]. One of the most cited research is conducted by Zhao and Astaneh-Asl [5]. They constructed a composite shear wall in their laboratory with a concrete panel and an external steel plate connected with several shear fasteners. They fabricated two types of this composite wall: one with a gap between the frame and the concrete panel named it as the innovative shear wall and another without this gap. They concluded at the end of their study that the innovative composite shear wall with the mentioned gap has more ductility and better performance under the seismic loads. In fact, by considering the mentioned gap, the premature crushing of the concrete panel which occurred in the conventional RC shear wall is prevented. In another important investigation on the behavior of composite shear wall, Hossain and Wright [6] fabricated a composite shear wall in the laboratory using profiled steel plates.
They compared the performance of this composite shear wall with the steel and $\mathrm{RC}$ shear walls and indicated that their new proposed composite shear wall exhibits more strength, stiffness, and ductility than the other two types of shear walls. Rafiei et al. [7] and Hossain et al. [8] conducted some valuable tests on the double skin profiled composite shear walls (DSCSWs). They studied the effects of some parameters include the compressive strength of concrete, the yield strength of the steel plate and the number of the shear stiffeners on the performance of their new proposed composite shear wall. According to the obtained results, they concluded that the DSCSW can provide significant shear capacity if a sufficient number of intermediate fasteners is used to connect the concrete panel to the profiled steel sheets. When the proper number of fasteners is implemented, the shear yielding of the steel plate occurs before that the elastic buckling of the plate can happen. Rassouli et al. [9] performed an experimental 
and numerical study on the behavior of the concrete-steel plate shear walls (CSPSWs) considering a light-weight concrete for the concrete panel. They found out based on their obtained results that the CSPSW is a reliable lateral load-resisting system. Their results also indicated that the shear capacity of the CSPSW with the light-weight concrete is approximately similar to the specimen with normal-weight concrete. Zhao et al. [10] conducted tests on 32 steel-concrete composite shear walls subjected to in-plane cyclic loading. They derived useful equations for calculating the stiffness and shear capacity of the composite shear walls. Wang et al. [11] investigated the seismic behavior of steel plate reinforced concrete composite shear wall (SPRW). They proposed a new type of composite shear wall consists of a steel plate encased in the middle of a reinforced concrete shear wall. They conducted some experimental tests on this composite wall under the cyclic shear load and developed a hysteretic curve model based on the test data. They reported that their new proposed composite wall has excellent seismic behaviors. Zhang et al. [12] constructed fifteen specimens of a new type of composite shear walls composed of two stiffened steel plates produced some vertical channels filled with concrete. These composite shear walls were tested under horizontal cyclic loads, along with a constant vertical axial force. According to the obtained results, Zhang and his team work concluded that their new proposed composite shear wall exhibits good deformation capacity. They also found that the number of vertical channels has a significant effect on the ductility but has a negligible effect on the shear load capacity of the wall. An experimental study was performed on the seismic behaviors of the corrugated steel plate and steel plate reinforced concrete shear walls by Wang et al. [13]. Based on the results obtained from this study, it was revealed that the load-bearing capacity, initial stiffness, and ductility of the steel-concrete composite shear wall are more than those of the corresponding steel plate shear wall. An analytical approach using composite shell theory was developed and implemented by Booth et al. [14] to calculate the entire in-plane shear force-shear strain response of steel-concrete composite shear walls. Booth and his co-workers indicated that their new proposed analytical method has reasonable accuracy when it is compared with the experimental and finite element method results. Nie et al. [15] investigated the cyclic lateral behavior of the reinforced concrete-filled composite plate shear walls (CPSW) under the effect of different high axial compression ratio ranging from 0.313 to 0.542 .
The test results obtained by Nie et al. showed that CPSW systems connected by shear studs have adequate ductility. Labibzadeh et al. [16] Obtained good results by comparing the performance of two newly developed concrete columns MTSTR and CFST under eccentric compressive loads. In this modeling, nonlinear finite element method is used. To simulate the behavior of concrete cores and steel columns, Concrete damage plasticity model and the elastic-perfect plastic model were used, respectively. This feature provides modeling of large nonlinear deformations of columns. The results show that MTSTR columns can provide higher load carrying capacity, flexibility and energy absorption with a slightly lower initial stiffness than CFST columns under similar eccentricities. For example, the loading capacity of the MTSTR column is $18 \%$ higher than that of the CFST column when the load eccentricity is $100 \mathrm{~mm}$. In case of $100 \mathrm{~mm}$ eccentricity, the flexibility of the improved version of the MTSTR column presented in this study is 30\% greater than that of the CFST. Gholipour et al. [17] made some observations about push over analysis of multi-story Steel Plate Shear Wall Structures. Pushover analysis is used to predict the nonlinear behavior of structural systems. An important factor, which significantly changes the results of the pushover analysis, is the pattern of lateral load distribution along the height of the structures. They designed five 4 to 13 -story SPSW frames according to AISC-341. Then, the frames were analyzed under the two lateral loading patterns recommended by FEMA-356. Raza et al. [18] conducted a numerical research on the load-carrying capacity of GFRP-reinforced rectangular concrete members using CDP model in ABAQUS. They found that their proposed models have excellent reliability and accuracy in prediction the behavior of such concrete elements. Mehmood et al. [19] have performed experimental and numerical seismic evaluation of RC walls under axial compression. A quasi-static inverse ring test was performed for two RC wall samples, one under axial load and the other without axial load to evaluate the effect of axial compression on the shear strength of RC walls in high-rise buildings. Experimental results were also compared with performance-based seismic code evaluation methods. They concluded that the axial load level is related to the available flexibility of RC shear walls. They also found that the ductility of the shear strain is reduced using the axial load. Raza et al. [20] performed a numerical investigation on HFRC columns reinforced with GFRP bars and spirals under concentric and eccentric loads. They concluded that both steel and GFRP-HFRC columns have similar failure modes. 
Tahir et al. [21] conducted an experimental and numerical research and investigated the effects of transverse circular holes (TCH) on load-carrying capacity of RC columns. They found that increasing column area to accommodate $\mathrm{TCH}$ is the most effective way among all the test options. Chaouch et al. [22] performed a numerical study on shear stress variation of RC wall with L- shaped section. In recent years, following the Boomerang earthquake in 2003, a new type of building was built in Algeria. The new concept is based on the concentration of shear walls of L-shaped reinforced concrete in the corners of the building. To evaluate the stress distribution at the base of L-shaped corner walls, numerical research has been performed on the concrete structure. In their study, the effect of story number, shear wall length and wall thickness was investigated. Generally, more than 200 numerical models were created and analyzed. Analyzes showed that a reinforced concrete wall with a thickness of $15 \mathrm{~cm}$ or less should be at least 10 times thicker. However, for RC walls with a thickness of more than $20 \mathrm{~cm}$, the wall length must be more than 7 times the thickness. Ahmad et al. [23] studied the behavior of CFRP-confined concrete cylinders. They used artificial neural network (ANN) to develop their strength models. Their comparative study demonstrated that the proposed ANN, FE, and theoretical models have good agreement with the experimental results. Mustafaraj and Yardim [24] studied in-plane shear strengthening of unreinforced masonry walls using GFRP jacketing. From the results of the diagonal compression test, some of the main mechanical parameters such as shear strength, modulus of rigidity and flexibility, were identified before and after the use of reinforcement. The experimental results showed that GFRP reinforced panels gain a significant increase of $127 \%$ in shear strength, $1100 \%$ in ductility and $650 \%$ in rigidity modulus compared to unreinforced panels. -

Regarding the above-mentioned reviewed research works and many more others which are not brought here due to the sake of brevity, it can be realized that the steel-concrete composite shear walls have distinct structural advantages over the steel or reinforced concrete shear walls. Thus, the need for more investigations concerning with the structural performance of composite shear walls appears self-evident. On the other hand, by examining the literature, the lake of performing a comparison between the performances of different composite shear walls is felt.

Accordingly, and to respond to the mentioned needs, a research study has been conducted (subject matter of this paper), for the first time, on the cyclic lateral behavior of various types of composite steel-concrete shear walls compared to a traditional reinforced concrete (RC) shear wall. The cyclic lateral behavior of four types of shear walls including a conventional (RC) shear wall (wall1) as the reference wall, a composite shear wall composed of a single external steel plate connected to a concrete panel (wall2), a composite shear wall constructed from two external steel plates connected to an internal concrete panel (wall3) and a composite shear wall fabricated with a single internal steel plate embedded within a concrete panel (wall4) are simulated with the finite element (FE) modeling using the ABAQUS software. At the first stage of the study, for each of the mentioned shear walls, an experimental test is considered based on the latest available literature and then that tested wall is modeled in the software and the obtained numerical results were compared with the corresponding test results to verify the validity of the FE model. After verifications, a parametric study is performed. Four parameters consisting of concrete compressive strength, height-tolength ratio of the wall, yield strength of the steel plate and steel plate thickness were selected to perform such a parametric study. Several numerical FE models were developed to investigate the effect of each of these above-mentioned parameters on the hysteretic shear load-displacement response, shear capacity, energy absorbing capacity, stiffness degradation of the shear walls. This study aims to recognize the seismic performance differences of the four aforementioned shear wall systems which will be helpful for the design applications.

\section{Numerical model development and verification}

Each FE model of the four types of the shear walls selected in this study to investigate their behaviors under lateral cyclic loading was verified against the corresponding experimental results. For the sake of the brevity, the model of the Zhao and Astaneh-Asl [5] shear wall (wall2) is presented here to show the verification (see Fig. 1). The test setup is shown in Fig. 1(a). Important parts of the test setup are: actuator, top loading beam, bottom reaction beam, $\mathrm{R} / \mathrm{C}$ reaction blocks, and bracings.

The actuator can provide $\pm 305 \mathrm{~mm}$ of maximum displacement and $\pm 6.672 \mathrm{kN}$ of maximum reciprocal force (push-pull force). It is fixed to a steel reaction box that is in turn fixed to the laboratory floor. The beam attached to the top of the specimen (the top loading beam) is designed to transfer cyclic horizontal actuator forces and displacements to the specimen. The beam attached to the bottom of the specimen is designed to transfer the shear forces and 


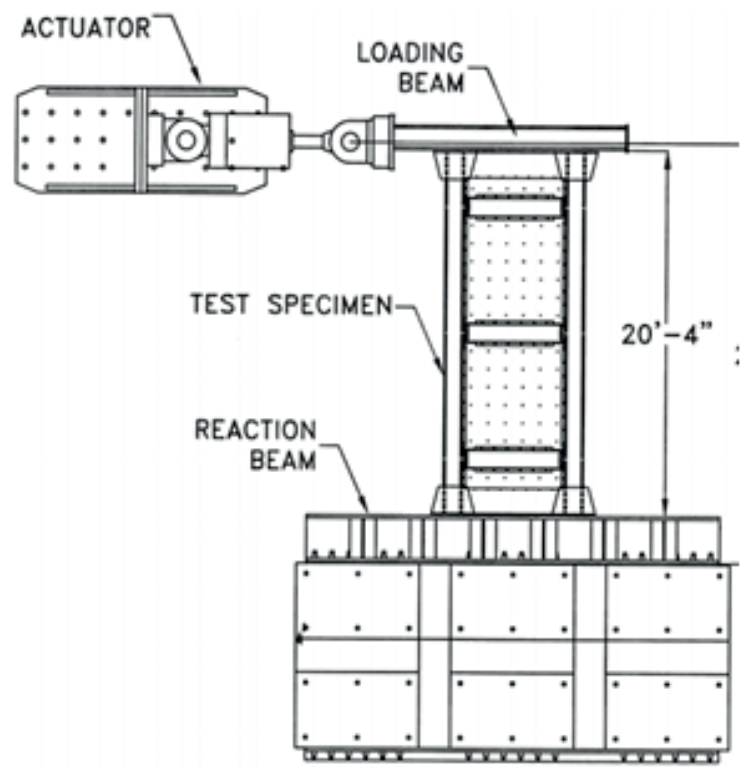

(a)

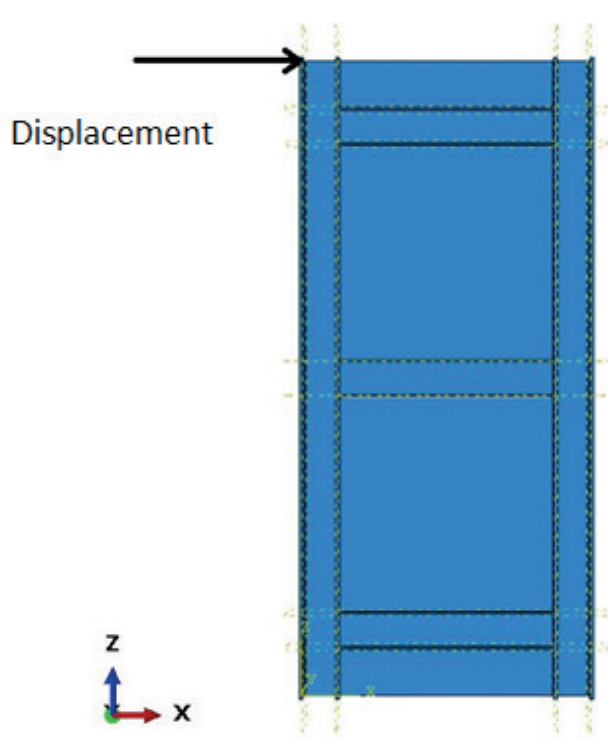

(b)

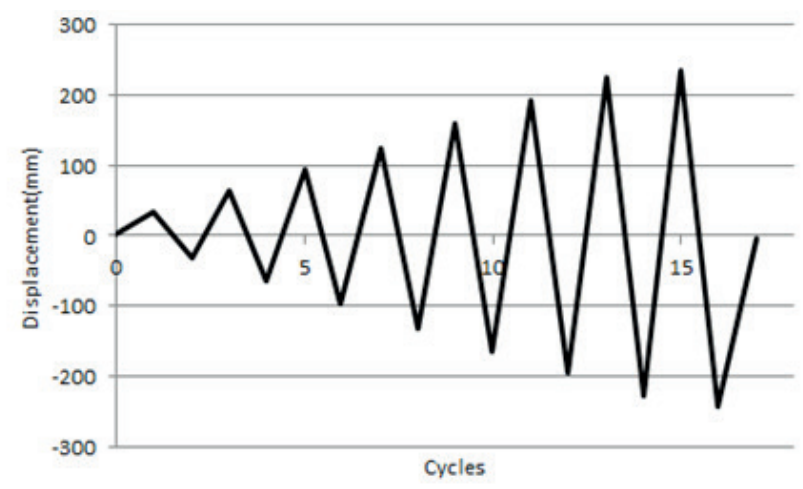

(c)

Fig. 1 Composite shear wall of Zhao and Astaneh-Asl [5]. a) Experimental test setup b) Corresponding FE model c) load sequence overturning moments from the specimen to the reaction blocks. The reaction blocks then transfer the shear forces and overturning moments to the ground. The FE model of the test setup developed in this study is illustrated in Fig. 1(b). The load sequence applied by the actuator to the top of the specimen is represented in Fig. 1(c). This load sequence is exactly simulated in the FE model. The material characteristics of the concrete and steel used in the test of the Zhao and Astaneh-Asl [5] are employed in the current numerical simulation. The Concrete Damaged Plasticity (CDP) model is implemented for the simulation of the concrete behavior $[25,26]$. The plasticity input parameters, compressive, and tensile behavior input parameters used in the CDP model are outlined in Tables $1-3$, respectively [27-31]. The plastic parameters in Table 1 are the optimized parameters and they are selected based on the previous studies of the author $[16,27,28]$. Several tries for dilation angle was selected between $5^{\circ}$ to $55^{\circ}$ and the optimized value was obtained as $30^{\circ}$. Likewise, for the eccentricity parameter, several attempts were selected between 0.1 to 1.0 and the best value was obtained as 0.1 .

An elastic-perfect plastic model isotropic hardening is also used for steel material modeling. The input parameters of the steel model are summarized in Table 4. The C3D8R and S4R elements are used to model the concrete and steel parts of the shear walls in the current study. To obtain the optimum size of the C3D8R elements used for concrete, three different sizes $(30,50$ and $70 \mathrm{~mm})$ are considered in the modeling and the resulting shear force-shear displacement curves are compared.

The different mesh sizes and obtaining curves are shown in Figs. 2 and 3, respectively. Time consumed for analysis under three different mesh sizes are plotted in Fig. 4.

Table 1 Input parameters of the elastic and plastic parts of the CDP model

\begin{tabular}{lcc}
\hline parameter & value & Description \\
\hline$\varnothing$ & 30 & Dilation angle \\
$e$ & 0.1 & $\begin{array}{c}\text { Eccentricity } \\
\text { Biaxial-to-uniaxial compressive } \\
\text { strength of concrete }\end{array}$ \\
$f_{b 0} / f_{c 0}$ & 1.16 & $\begin{array}{c}\text { Ratio of distance of compressive to } \\
k_{c}\end{array}$ \\
$\mu$ & 0.6667 & $\begin{array}{c}\text { Consile meridians from hydrostatic axis } \\
f_{c}(\mathrm{MPa})\end{array}$ \\
$\rho\left(10^{-9} \frac{\text { ton }^{3}}{\mathrm{~mm}^{3}}\right)$ & 2.001 & Compressive strength \\
$f_{c}(\mathrm{MPa})$ & 31411 & Concrete modulus of elasticity \\
$v$ & 0.2 & Poisson's ratio \\
\hline
\end{tabular}


Table 2 Input parameters of the compressive behavior of CDP model

\begin{tabular}{|c|c|c|c|}
\hline \multicolumn{2}{|c|}{ Compressive stress-inelastic strain } & \multicolumn{2}{|c|}{ Compressive Damage } \\
\hline Yield stress & inelastic Strain & $\begin{array}{c}\text { Damage } \\
\text { Parameter }\end{array}$ & $\begin{array}{c}\text { inelastic } \\
\text { Strain }\end{array}$ \\
\hline 10.42 & 0 & 0 & 0 \\
\hline 12.36 & 0.000022 & 0 & 0.000022 \\
\hline 14.29 & 0.000044 & 0 & 0.000044 \\
\hline 17.71 & 0.000107 & 0 & 0.000107 \\
\hline 24.45 & 0.000436 & 0 & 0.000436 \\
\hline 26.04 & 0.000838 & 0 & 0.000838 \\
\hline 23.44 & 0.00214 & 0.1 & 0.00214 \\
\hline 20.83 & 0.00345 & 0.2 & 0.00345 \\
\hline 18.23 & 0.00475 & 0.3 & 0.00475 \\
\hline 15.62 & 0.00606 & 0.4 & 0.00606 \\
\hline 13.02 & 0.00736 & 0.5 & 0.00736 \\
\hline 10.42 & 0.00867 & 0.6 & 0.00867 \\
\hline 7.81 & 0.00997 & 0.7 & 0.00997 \\
\hline 5.21 & 0.01128 & 0.8 & 0.01128 \\
\hline 2.60 & 0.01258 & 0.9 & 0.01258 \\
\hline 1.44 & 0.01316 & 0.95 & 0.01316 \\
\hline
\end{tabular}

Table 3 Input parameters of the tensile behavior of CDP model

\begin{tabular}{lccc}
\hline Tensile stress-cracking strain & \multicolumn{2}{c}{ Tensile Damage } \\
Yield stress & Cracking Strain & $\begin{array}{c}\text { Damage } \\
\text { Parameter }\end{array}$ & $\begin{array}{c}\text { Cracking } \\
\text { Strain }\end{array}$ \\
\hline 2.64 & 0 & 0 & 0 \\
2.35 & 0.000106 & 0.1 & 0.000106 \\
2.06 & 0.000235 & 0.2 & 0.000235 \\
1.78 & 0.000352 & 0.3 & 0.000352 \\
1.49 & 0.000470 & 0.4 & 0.000470 \\
1.20 & 0.000587 & 0.5 & 0.000587 \\
0.92 & 0.000705 & 0.6 & 0.000705 \\
0.63 & 0.000822 & 0.7 & 0.000822 \\
0.34 & 0.000940 & 0.8 & 0.000940 \\
\hline
\end{tabular}

Table 4 Input parameters of the steel model

\begin{tabular}{lccc}
\hline Profile & Reinforcing bars & Plate & Parameter \\
\hline 520 & 600 & 370 & $f_{u}(\mathrm{MPa})$ \\
345 & 400 & 248 & $f_{v}(\mathrm{MPa})$ \\
7.86 & 7.86 & 7.86 & $\rho\left(10^{-9} \frac{\mathrm{ton}}{\mathrm{mm}^{3}}\right)$ \\
$2 \mathrm{e} 5$ & $2 \mathrm{e} 5$ & $1.9 \mathrm{e} 5$ & $f_{c}(\mathrm{MPa})$ \\
0.3 & 0.3 & 0.3 & $v$ \\
\hline
\end{tabular}

According to the accuracy observed in Fig. 3, and calculation time are given in Fig. 4, the optimum size was chosen as $50 \mathrm{~mm}$. The obtained hysteretic loops from the numerical model developed in the current study are compared with the corresponding loops extracted from the test performed by Zhao and Astaneh-Asl [5] in Fig. 5.
It can be seen from Fig. 5 that there is a good agreement between the shear capacities (the summits of the hysteretic loops) predicted by the numerical model and those of the experimental test (Zhao and Astaneh-Asl [5]) in successive loading and unloading cycles. This can be observed better in Fig. 6 in which the envelope curves (skeleton

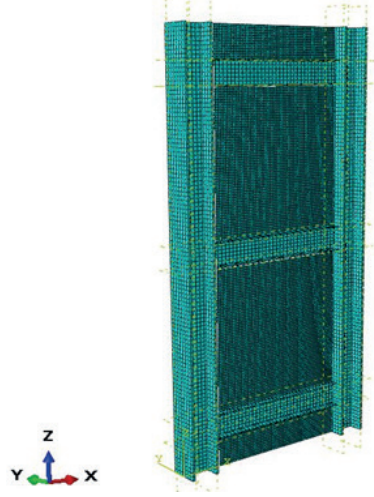

(a)

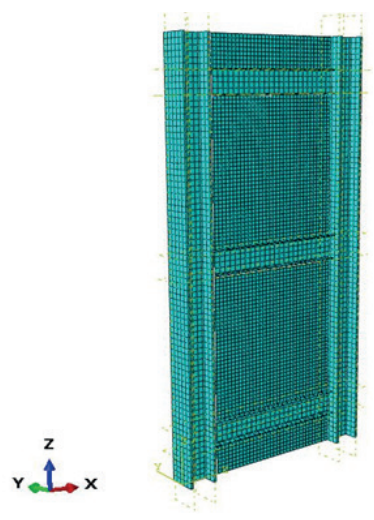

(b)

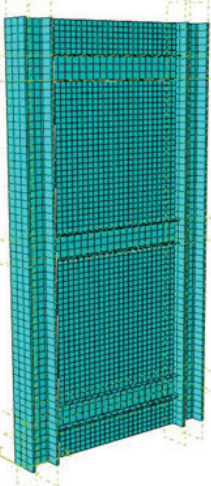

(c)
Fig. 2 Different mesh sizes of the wall 2 model (a) 50724 elements of size $30 \mathrm{~mm}$; (b) 22276 elements of size $50 \mathrm{~mm}$; (c)14464 elements of size $70 \mathrm{~mm}$

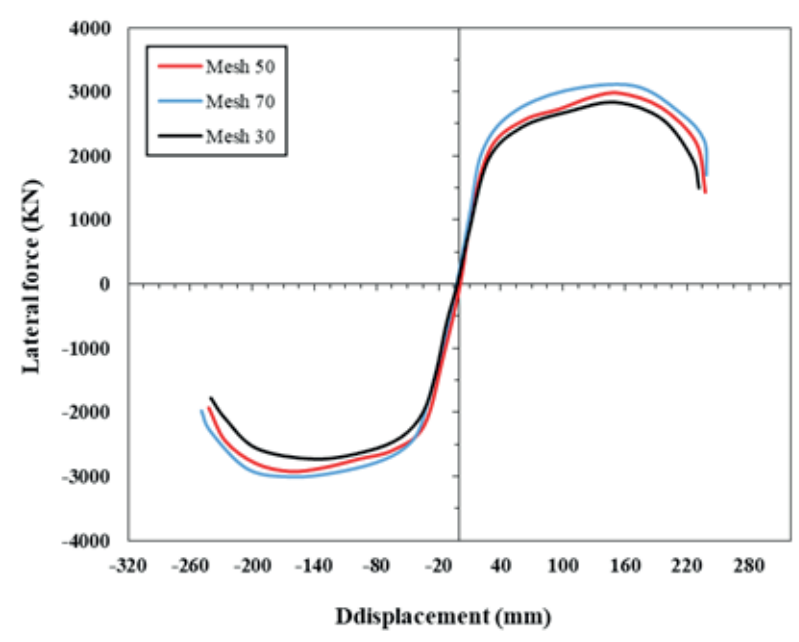

Fig. 3 Effect of different mesh sizes on the shear load-displacement curve of the wall 2 model 


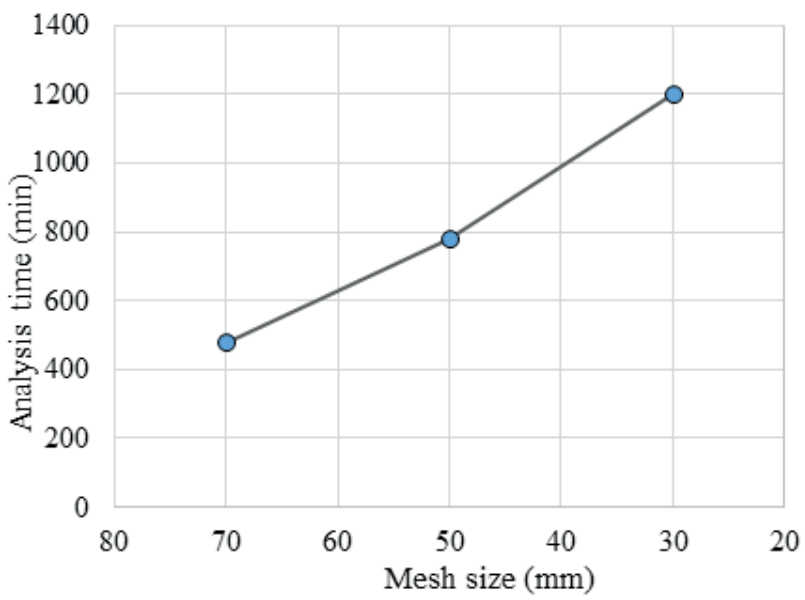

Fig. 4 Effect of different mesh sizes on analysis time of the wall2 model

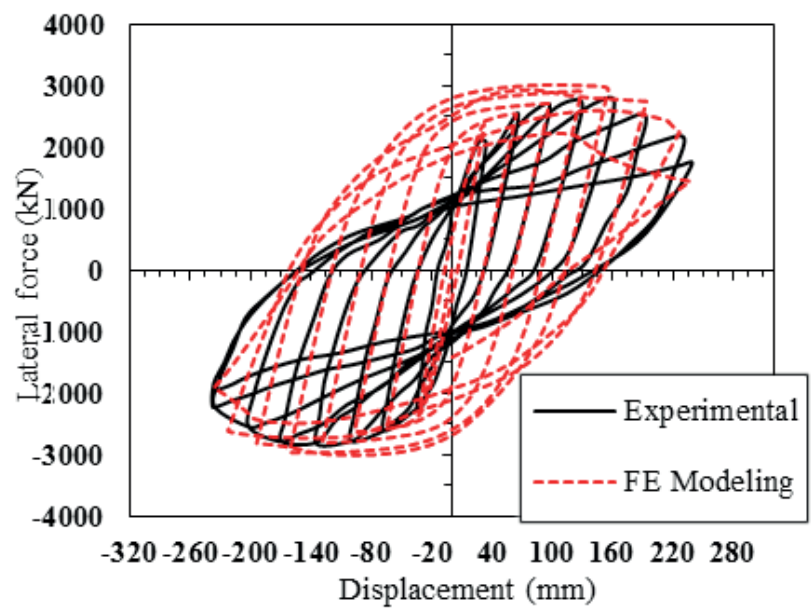

Fig. 5 Comparison of the hysteretic loops of the experimental test and corresponding numerical model (wall2)

curves) of the test and numerical model are compared. The model developed in the current study can represent the reduction in the shear capacity due to degradation in the concrete strength and yielding and buckling occurred in the steel plate. However, the model cannot simulate the pinching of the hysteretic loops observed in the test. This is because the CDP model of concrete in the ABAQUS software could not predict well the stiffness degradation in the unloading branches of the hysteretic loops.

\section{Numerical parametric study}

After verification of the models, the effects of four parameters such as compressive strength of the concrete, yield strength of the steel plate, height-to-length ratio of the shear wall and thickness of the steel plate on the shear performance of the four types of shear walls mentioned earlier in the introduction were investigated. Thirty-nine numerical model walls are described in Table 5.

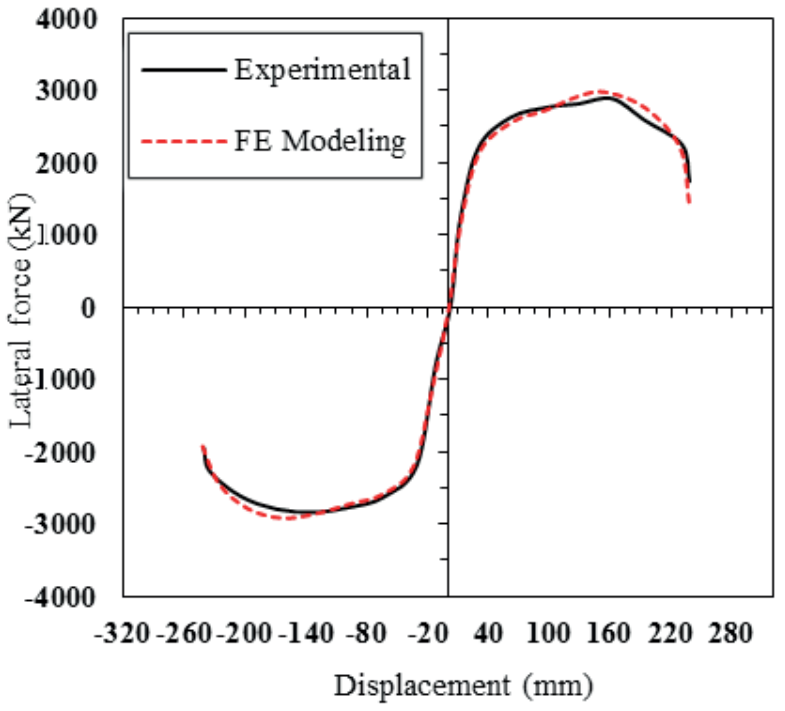

Fig. 6 Comparison of the skeleton curves of the experimental test and that of the numerical model (wall2)

\subsection{Effect of concrete strength}

The effect of two different compressive strengths of concrete panel: $30 \mathrm{MPa}(\mathrm{Fc} 1)$ and $60 \mathrm{MPa}(\mathrm{Fc} 2)$ on the shear capacity is investigated by comparing the shear load-shear displacement curves of each of the shear walls (see Fig. 7). It can be noted from this figure that the increase of concrete compressive strength has no noticeable effect on the shear capacity of composite shear walls (wall2, wall3, and wall4) and it only make the shear capacity of conventional RC shear wall to increase. This result demonstrates that the shear capacity of composite shear walls depends strongly on the shear capacity of steel plates and the concrete panel plays the role of the lateral support for the steel plates preventing the plate buckling. Fig. 8 shows the effect of concrete compressive strength on the energy dissipation capacity of the shear walls. The dissipated energy by all four types of shear walls is found to increase with the increase of concrete compressive strength. Furthermore, the wall4 has exhibited the highest energy dissipation capacity $(6709 \mathrm{kN} . \mathrm{m})$ among the four types of shear walls. This is because, in the wall4, the steel plate is embedded within the concrete panel and the buckling is prevented at all stages of the cyclic loadings. The stiffness degradation of the shear walls during the lateral cyclic loading is compared in Fig. 9 under the effect of the compressive strength of concrete. It is obvious from this figure that the compressive strength of concrete has the biggest effect on the stiffness of wall1 and wall 2 among the others. This is because of the fact that the concrete in wall 3 and wall4 is unreinforced and has played only the role of the lateral support for 
Table 5 Definition of the models used for parametric study

\begin{tabular}{|c|c|c|c|c|c|c|}
\hline Model type & Model no & Model name & $\begin{array}{l}\text { Height-to-length } \\
\text { ratio }\end{array}$ & $\begin{array}{l}\text { Compressive strength of } \\
\text { concrete }(\mathrm{MPa}) \mathrm{Fc}\end{array}$ & $\begin{array}{l}\text { Yield strength of } \\
\text { steel (MPa) Fy }\end{array}$ & $\begin{array}{l}\text { Plate thickness } \\
\qquad(\mathrm{mm})\end{array}$ \\
\hline \multirow{6}{*}{ wall1 } & 1 & $\mathrm{FCl}$ & $1: 1$ & 30 & - & - \\
\hline & 2 & FC2 & $1: 1$ & 60 & - & - \\
\hline & 3 & HL1 & $1: 1$ & 30 & - & - \\
\hline & 4 & HL2 & $1: 1.5$ & 30 & - & - \\
\hline & 5 & HL3 & $2: 1$ & 30 & - & - \\
\hline & 6 & HL4 & 3:1 & 30 & - & - \\
\hline \multirow{11}{*}{ Wall2 } & 7 & $\mathrm{Fcl}$ & $1: 1$ & 30 & 370 & 4.8 \\
\hline & 8 & $\mathrm{Fc} 2$ & $1: 1$ & 60 & 370 & 4.8 \\
\hline & 9 & Fy1 & $1: 1$ & 30 & 370 & 4.8 \\
\hline & 10 & Fy2 & $1: 1$ & 30 & 520 & 4.8 \\
\hline & 11 & HL1 & $1: 1$ & 30 & 370 & 4.8 \\
\hline & 12 & HL2 & $1: 1.5$ & 30 & 370 & 4.8 \\
\hline & 13 & HL3 & $2: 1$ & 30 & 370 & 4.8 \\
\hline & 14 & HL4 & $3: 1$ & 30 & 370 & 4.8 \\
\hline & 15 & TS1 & $1: 1$ & 30 & 370 & 4.8 \\
\hline & 16 & TS2 & $1: 1$ & 30 & 370 & 8 \\
\hline & 17 & TS3 & $1: 1$ & 30 & 370 & 11 \\
\hline \multirow{11}{*}{ Wall3 } & 18 & $\mathrm{Fc} 1$ & 1:1 & 30 & 370 & 4.8 \\
\hline & 19 & $\mathrm{Fc} 2$ & $1: 1$ & 60 & 370 & 4.8 \\
\hline & 20 & Fy1 & $1: 1$ & 30 & 370 & 4.8 \\
\hline & 21 & Fy2 & $1: 1$ & 30 & 520 & 4.8 \\
\hline & 22 & HL1 & $1: 1$ & 30 & 370 & 4.8 \\
\hline & 23 & HL2 & $1: 1.5$ & 30 & 370 & 4.8 \\
\hline & 24 & HL3 & $2: 1$ & 30 & 370 & 4.8 \\
\hline & 25 & HL4 & $3: 1$ & 30 & 370 & 4.8 \\
\hline & 26 & TS1 & 1:1 & 30 & 370 & 4.8 \\
\hline & 27 & TS2 & $1: 1$ & 30 & 370 & 8 \\
\hline & 28 & TS3 & $1: 1$ & 30 & 370 & 11 \\
\hline \multirow{11}{*}{ Wall4 } & 29 & $\mathrm{Fc} 1$ & $1: 1$ & 30 & 370 & 4.8 \\
\hline & 30 & $\mathrm{Fc} 2$ & 1:1 & 60 & 370 & 4.8 \\
\hline & 31 & Fy1 & 1:1 & 30 & 370 & 4.8 \\
\hline & 32 & Fy2 & 1:1 & 30 & 520 & 4.8 \\
\hline & 33 & HL1 & $1: 1$ & 30 & 370 & 4.8 \\
\hline & 34 & HL2 & $1: 1.5$ & 30 & 370 & 4.8 \\
\hline & 35 & HL3 & $2: 1$ & 30 & 370 & 4.8 \\
\hline & 36 & HL4 & $3: 1$ & 30 & 370 & 4.8 \\
\hline & 37 & TS1 & 1:1 & 30 & 370 & 4.8 \\
\hline & 38 & TS2 & 1:1 & 30 & 370 & 8 \\
\hline & 39 & TS3 & $1: 1$ & 30 & 370 & 11 \\
\hline
\end{tabular}

the steel faceplates. However, in walls 1 and 2, the concrete is reinforced and plays a direct role in resisting the lateral applied loads. It is also worth mentioning that the wall1 has the highest initial stiffness, but at the same has the biggest stiffness degradation during the cycles of load.

\subsection{Effect of height-to-length ratio}

The effect of height-to-length ratio on the shear capacity of the shear walls is investigated in this study. To assess the effect of this parameter, four different height-to-length ratios (1, 0.67, 2 and 3 named here as HL1 to HL4, respectively) 
(a)

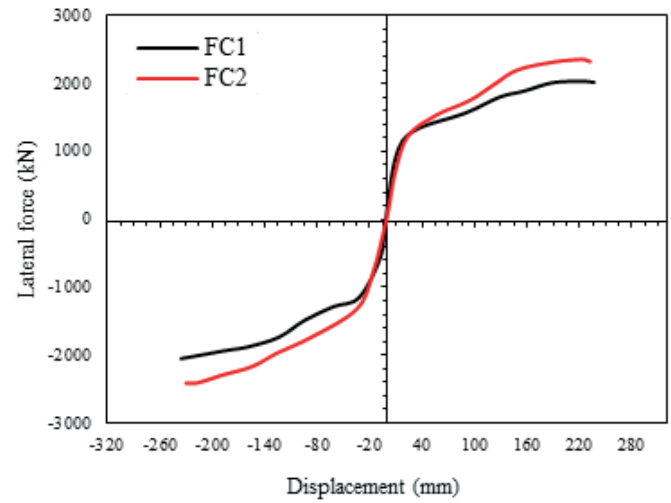

(c)

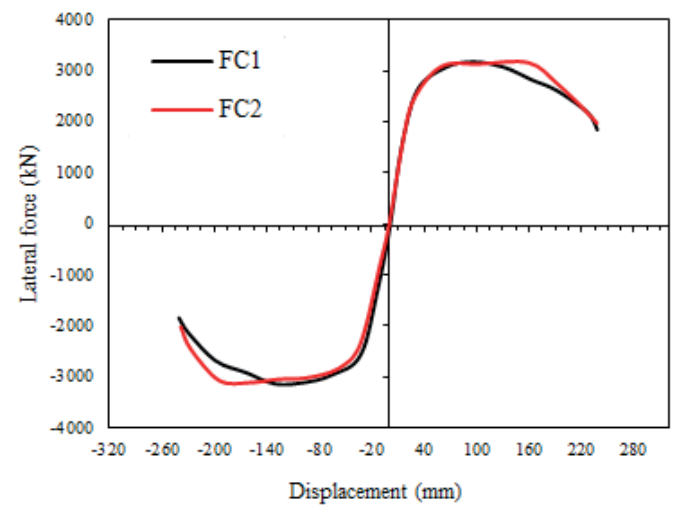

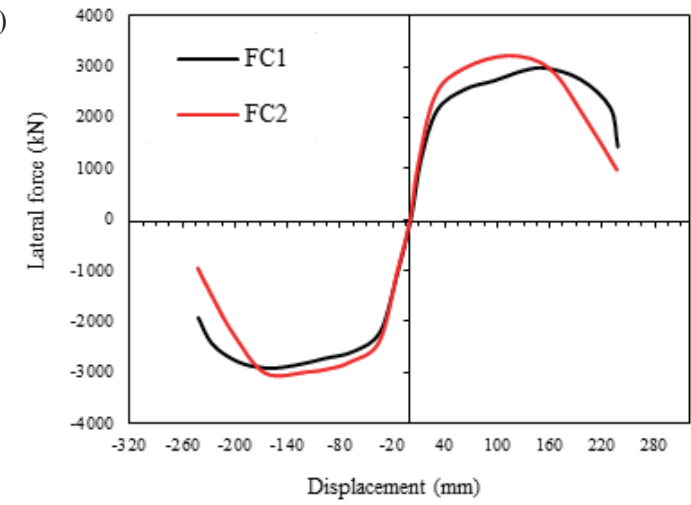

(d)

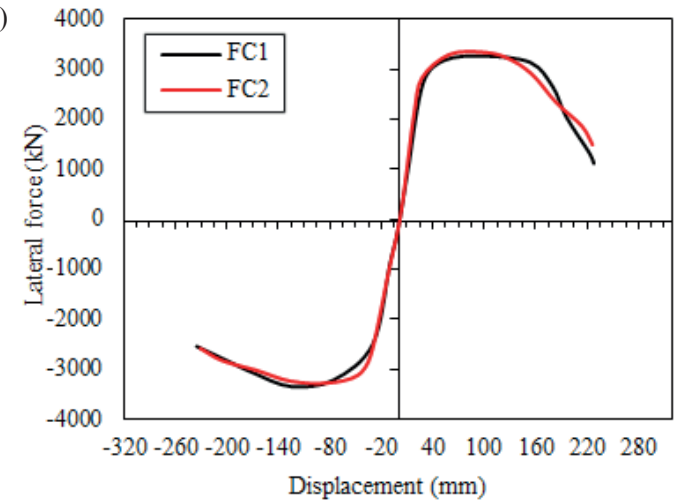

Fig. 7 Effect of compressive strength of concrete $(\mathrm{Fc} 1=30 \mathrm{MPa}, \mathrm{Fc} 2=60 \mathrm{MPa})$ on the skeleton curves of the shear capacity of the shear walls (a) Wall1; (b) Wall2; (c) Wall3; (d) Wall4

(a)

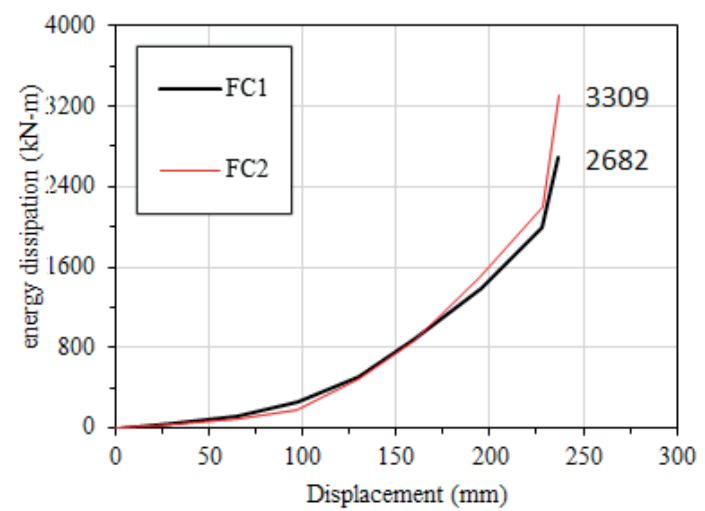

(c)

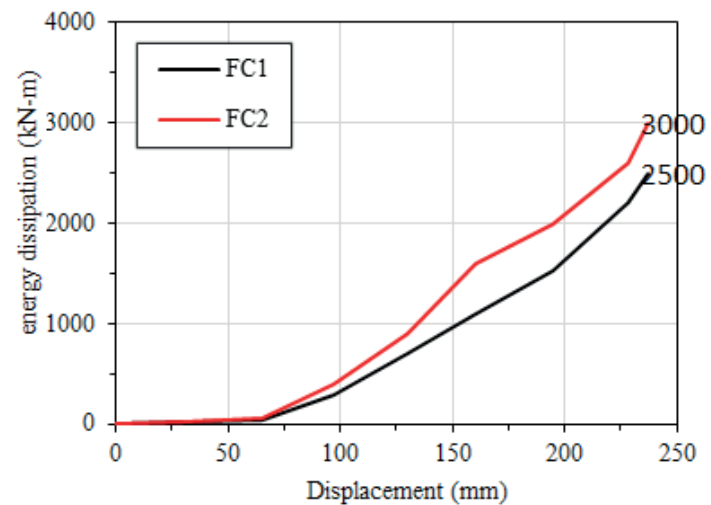

(b)

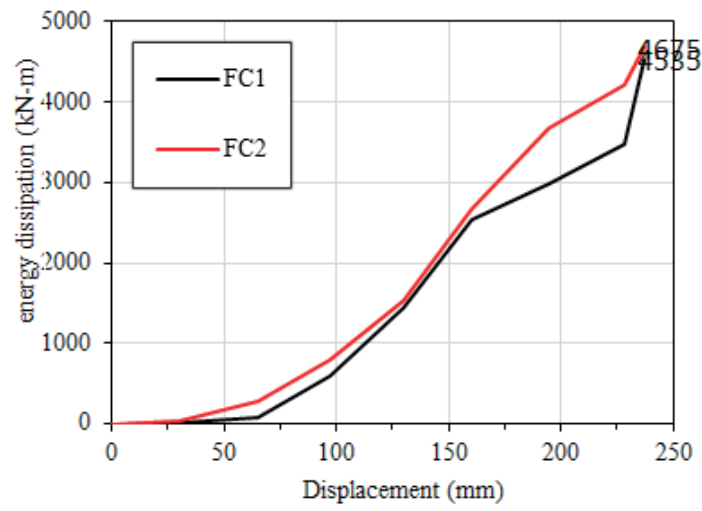

(d)

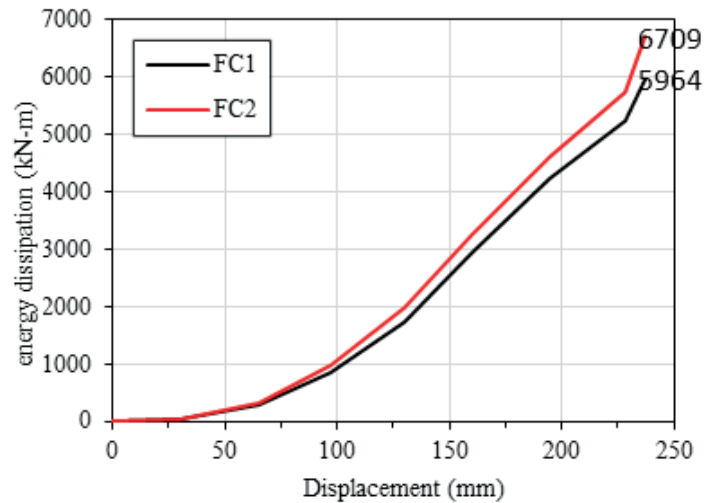

Fig. 8 Effect of compressive strength of concrete $(\mathrm{Fc1}=30 \mathrm{MPa}, \mathrm{Fc} 2=60 \mathrm{MPa})$ on the skeleton curves of the dissipated energy of the shear walls (a) Wall1; (b) Wall2; (c) Wall3; (d) Wall4 
(a)

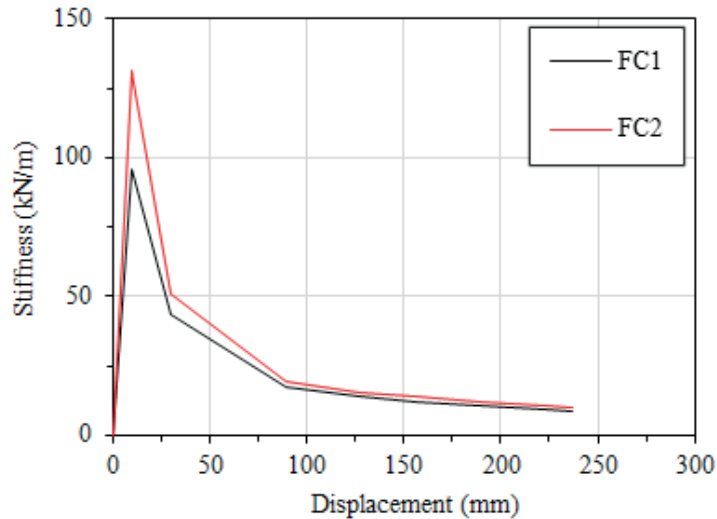

(c)

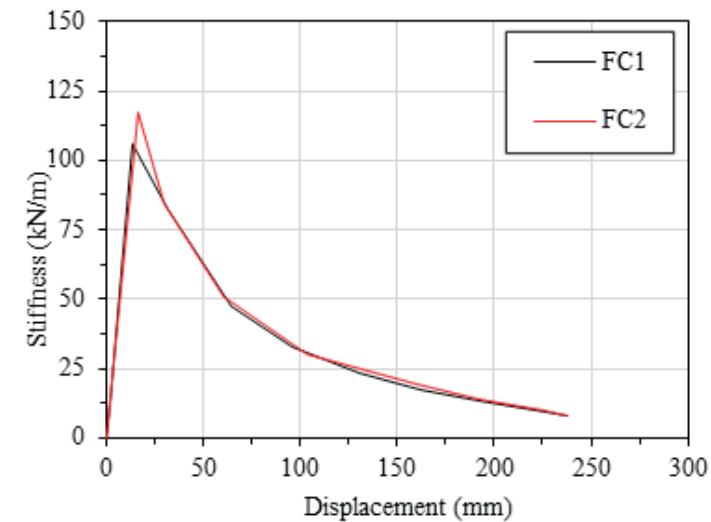

(b)

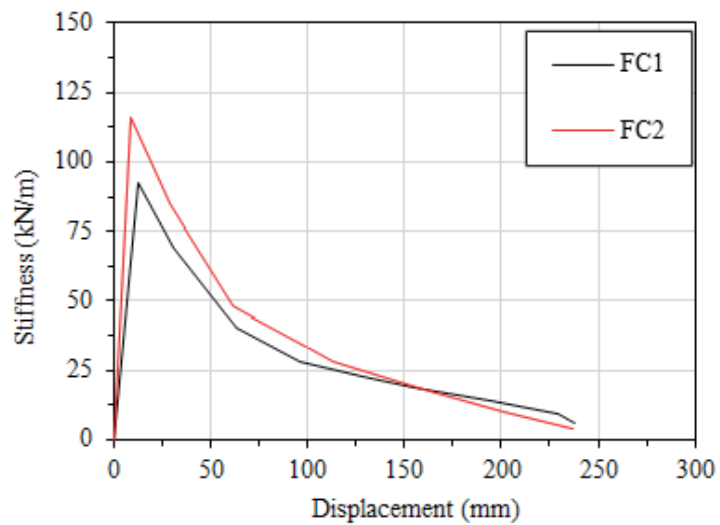

(d)

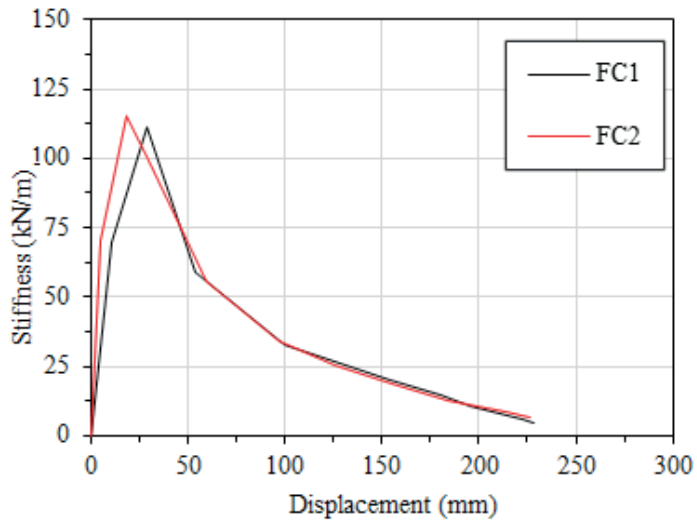

Fig. 9 Effect of compressive strength of concrete $(\mathrm{Fc} 1=30 \mathrm{MPa}, \mathrm{Fc} 2=60 \mathrm{MPa})$ on the skeleton curves of the stiffness degradation of the shear walls (a) Wall1; (b) Wall2; (c) Wall3; (d) Wall4

for each type of the shear walls are simulated and analyzed in the ABAQUS software under the effect of cyclic shear loading. These shear behaviors are illustrated in Figs. 10-12.

According to the lateral load-displacement skeleton curves of Fig. 10, it can be observed that the height-tolength ratio parameter has approximately the same effect on the shear capacity of the four types of shear walls. Among the four height-to-length ratios, the HL2 with the ratio of 0.67 (length of the wall is two times greater than its height) has the strongest effect on the improvement of the shear capacity in all types of walls. The skeleton curves of the energy dissipation of the shear walls are depicted in Fig. 11. It is obvious from this figure (similar to Fig. 10) that for all four types of shear walls, the height-tolength ratio equal to 1:1.5 has produced the highest capacity for energy dissipation. Moreover, according to Fig. 11, the wall4 specimen has exhibited the highest capacity of energy damping among the four types of shear walls.

Fig. 12 demonstrates the envelope curves of degradation of the stiffness during the lateral cyclic loading. It can be deduced from this curves that the wall (in all the four types of shear walls) with height-to-length ratio of 1:1.5 has the smallest degradation of the stiffness (in all specimens, the red curve is located above the other curves). Wall1 has the biggest reduction in the stiffness during the initial two cycles of loading (67\% reduction) but at the same time has the largest initial stiffness of $310 \mathrm{kN} / \mathrm{m}$. Among the composite shear walls, the wall4 shows the highest initial lateral stiffness of $175 \mathrm{kN} / \mathrm{m}$ and wall3 has the lowest initial stiffness of $125 \mathrm{kN} / \mathrm{m}$.

\subsection{Effect of yield strength of steel plate}

Two different yield strengths (Fy1 $=370 \mathrm{MPa}$ and Fy2 $=520$ $\mathrm{MPa}$ ) are considered to model the seismic behavior of the composite shear walls. Fig. 13 shows the effect of yield strength of the steel plate on the shear load-displacement envelope curves of composite shear walls. The change in the yield strength of the steel plate has not a significant effect on the shear capacity of the composite shear walls. Among the three types of the composite shear walls considered in the current study, the wall 2 shows the biggest gain in shear load $(6.5 \%$ compared to $1.6 \%$ and $2.8 \%$ of wall3 and wall4, respectively) when the yield strength of steel plate increase from $360 \mathrm{MPa}$ to $520 \mathrm{MPa}$. 
(a)

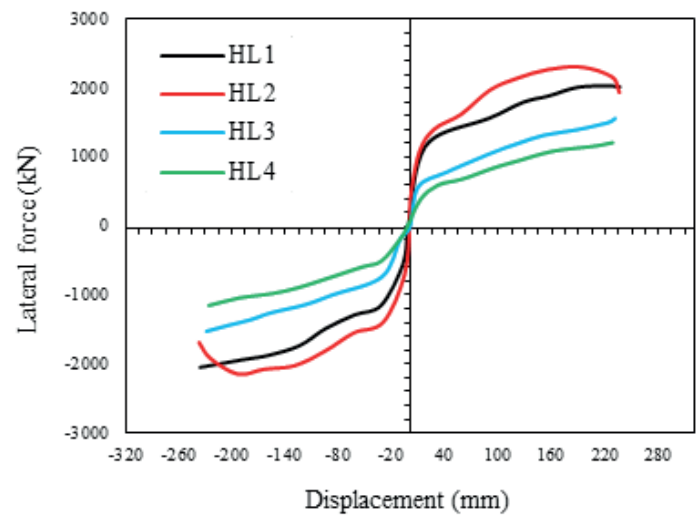

(c)

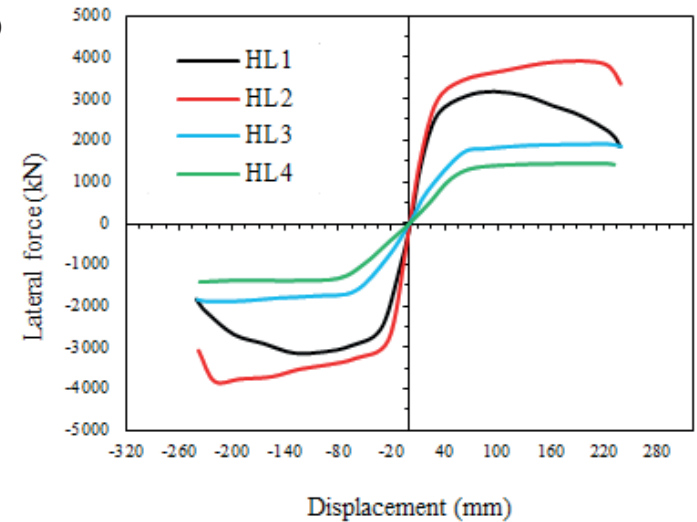

(b)

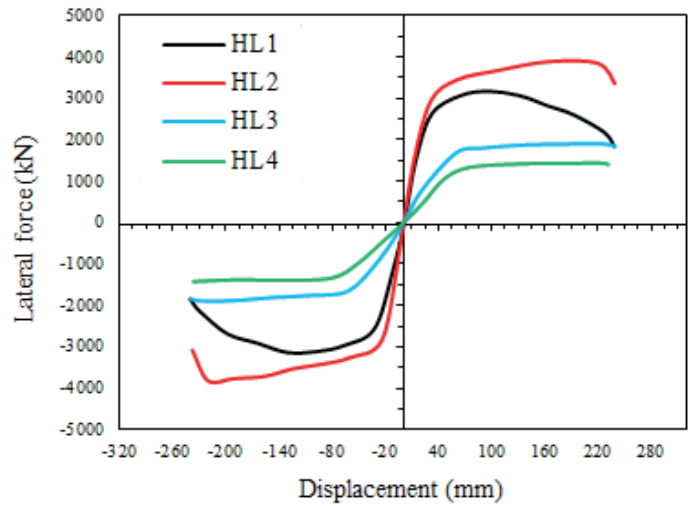

(d)

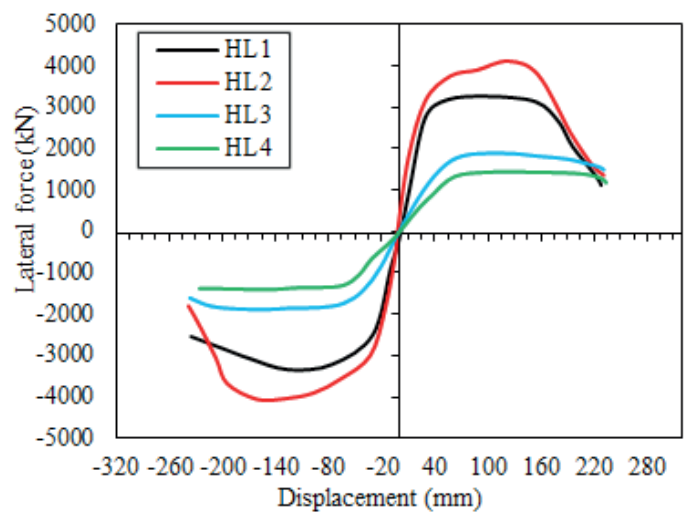

Fig. 10 Effect of height-to-length ratio (HL1=1, HL2=0.67, HL3=2, HL4=3) on the skeleton curve of shear capacity of the shear walls (a) Wall1; (b) Wall2; (c) Wall3; (d) Wall4

(a)

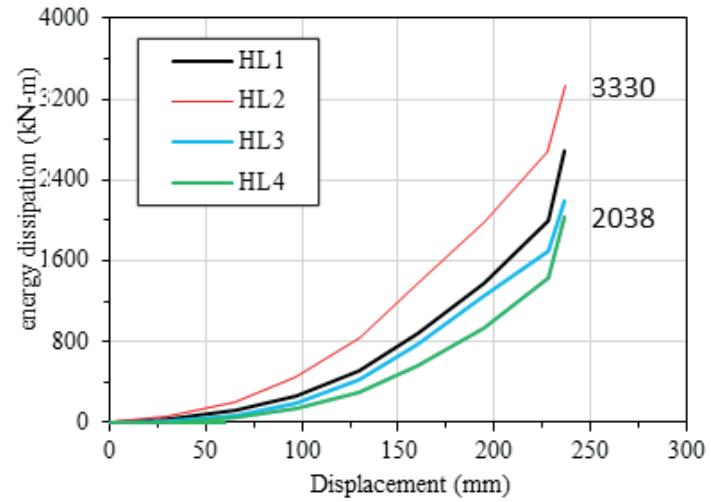

(c)

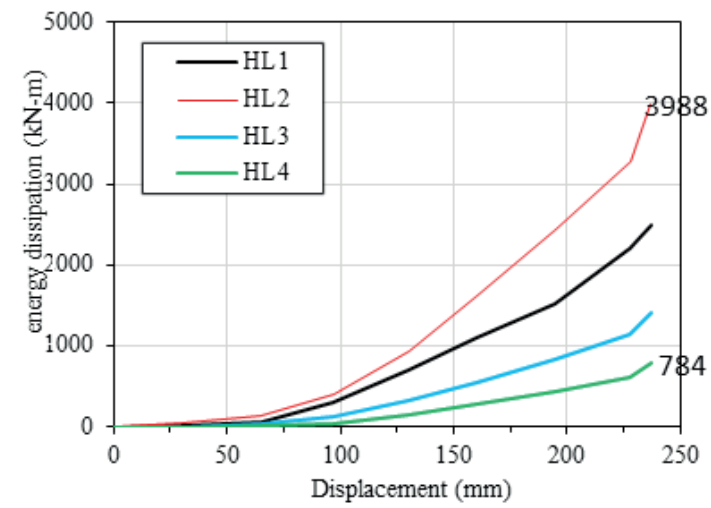

(b)

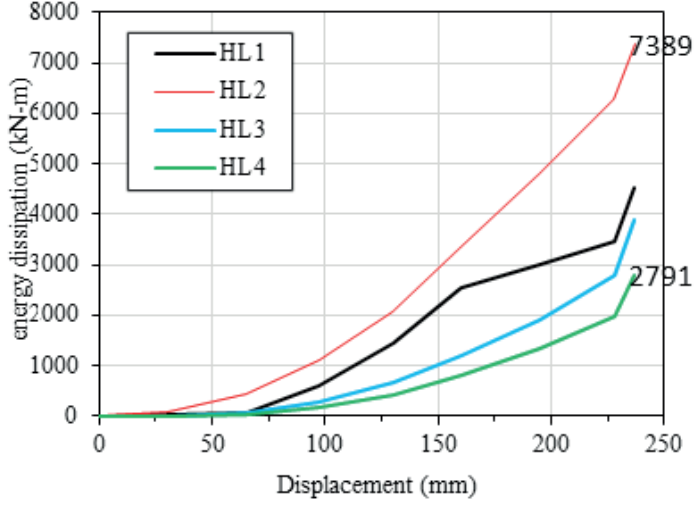

(d)

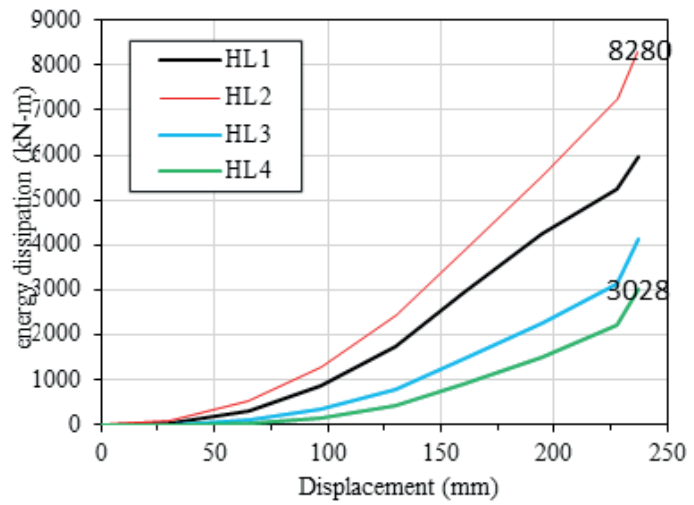

Fig. 11 Effect of height-to-length ratio (HL1=1, HL2=0.67, HL3=2, HL4=3) on the skeleton curve of energy dissipation of the shear walls (a) Wall1; (b) Wall2; (c) Wall3; (d) Wall4 
(a)

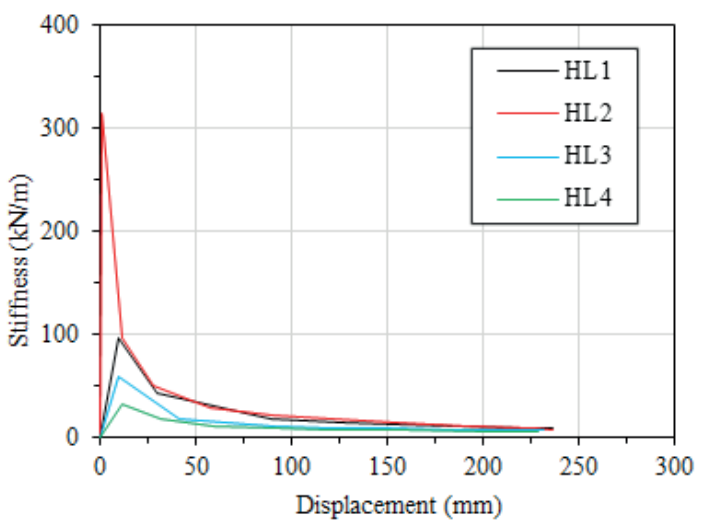

(c)

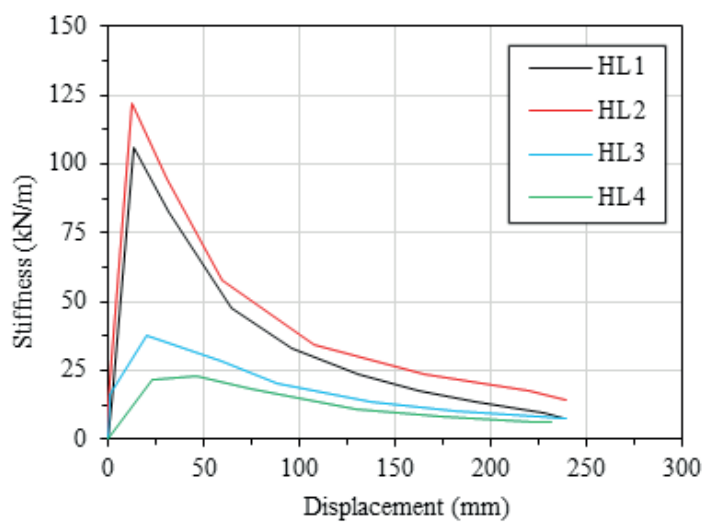

(b)

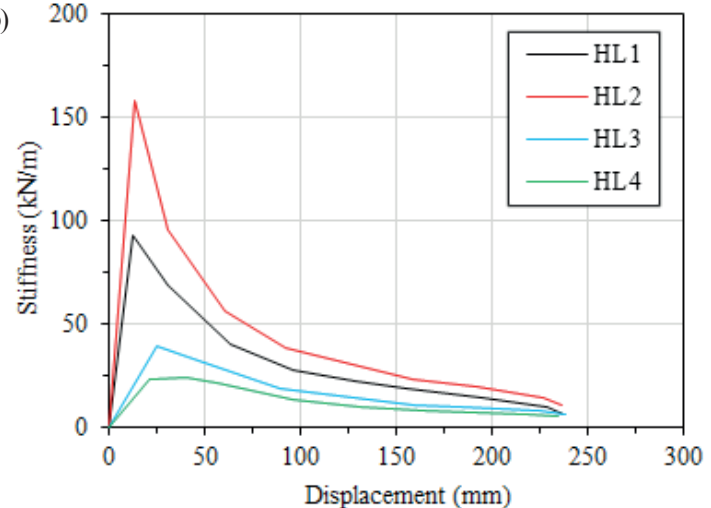

(d)

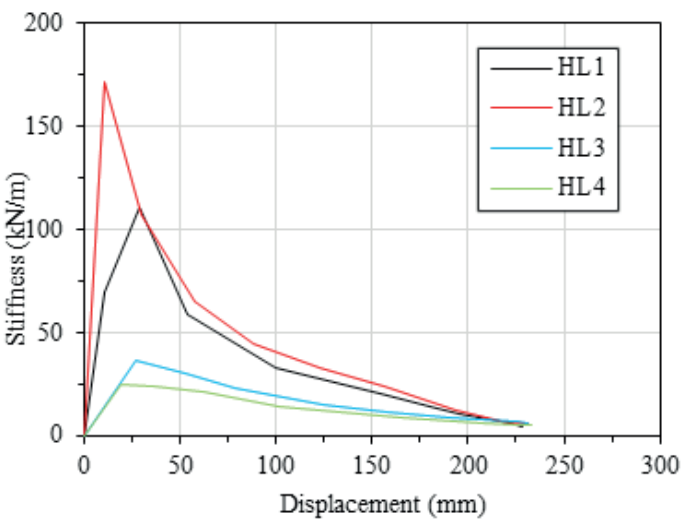

Fig. 12 Effect of height-to-length ratio (HL1=1, HL2=0.67, HL3=2, HL4=3) on the skeleton curve of stiffness degradation of the shear walls (a) Wall1; (b) Wall2; (c) Wall3; (d) Wall4

(a)

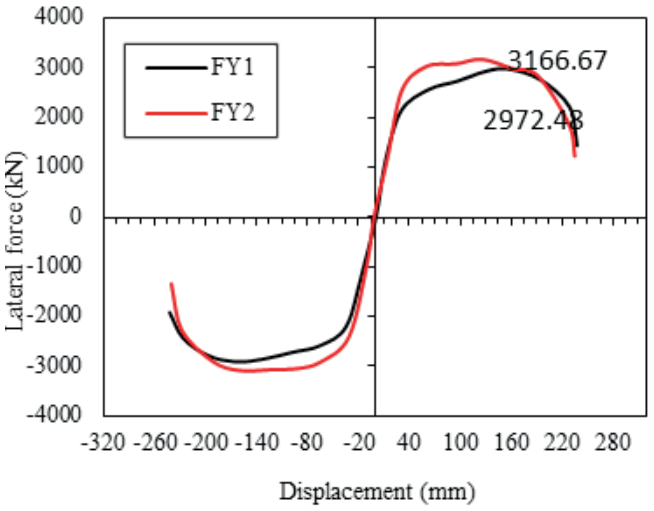

(b)

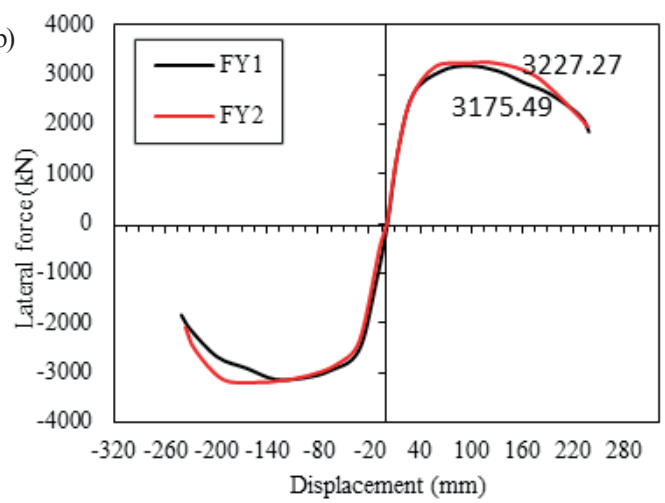

(c)

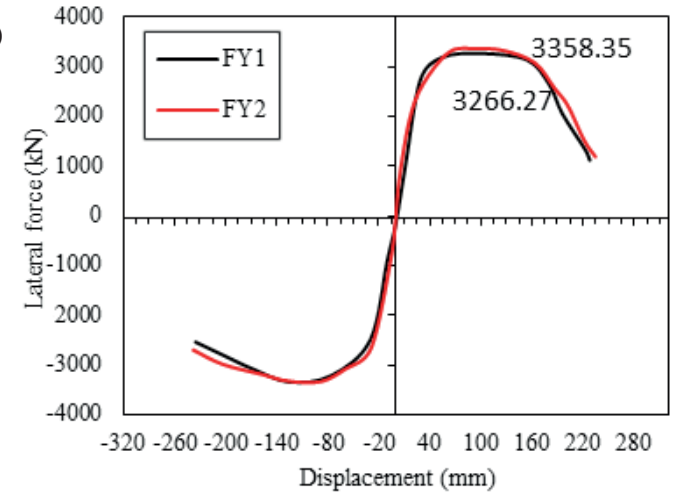

Fig. 13 Effect of yield strength of steel plate $(\mathrm{Fy} 1=370 \mathrm{MPa}, \mathrm{Fy} 2=520 \mathrm{MPa})$ on the skeleton curve of shear capacity of the shear walls 
The variation of energy absorption capacity of the composite shear walls with the change in the yield strength of steel plate is depicted in Fig. 14. In contrast to the shear capacity, the energy absorption capacity of the composite shear walls is sensitive to the change in yield strength of the steel plate. It is worth to note that the degree of this sensitivity is not the same for all wall specimens. Wall2 shows the largest dependency of the energy absorption capacity to the change in yield strength and wall demonstrates the least. This is because of the smallest shear buckling resistance of steel plate in wall2 and the largest in wall4. Wall4 using the steel plate of $520 \mathrm{MPa}$ yield strength has exhibited the highest energy dissipation capacity with 5\% and $\% 50 \%$ higher than wall 2 and 3 , respectively.

The change in lateral shear stiffness of the composite shear walls with varying yield strength of the steel plate is presented in Fig. 15. The most significant effect of yield strength of steel plate on the lateral stiffness is observed for wall4 while no noticeable effect on lateral stiffness is observed for the other composite shear walls, the use of high-strength steel has increased the stiffness of wall4 up to $180 \mathrm{kN} / \mathrm{m}$ while the highest stiffness of about $112 \mathrm{kN} / \mathrm{m}$ is observed for wall 2 and wall3. This can be attributed to the highest shear buckling resistance of the steel plate in wall4.

(a)

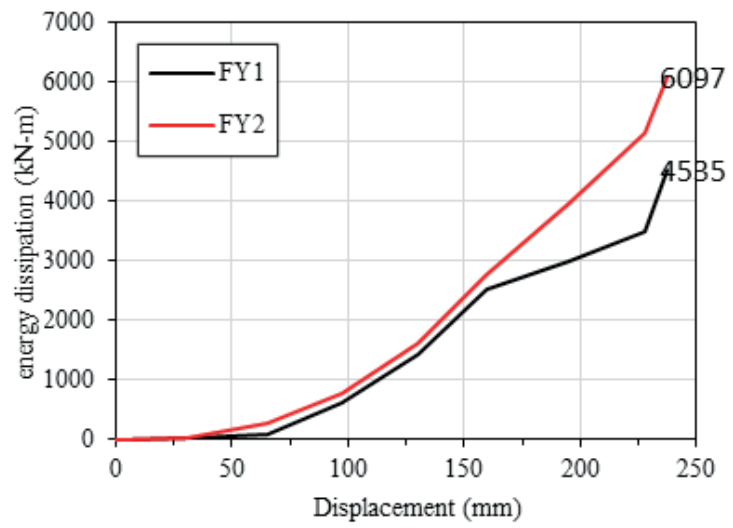

\subsection{Effect of thickness of steel plate}

The fourth parameter that can affect the seismic behavior of the composite shear walls is the steel plate thickness. To take into account the effect of this parameter, three different thicknesses were selected for the steel plates: TS1 $=4.8$ $\mathrm{mm}, \mathrm{TS} 2=8 \mathrm{~mm}$, and TS $3=11 \mathrm{~mm}$. The effect of change in the plate thickness on the shear capacity of the composite shear walls is evaluated and the results in the form of lateral load-displacement responses are presented in Fig. 16. The effect of plate thickness on the shear capacity is found to be considerable for wall 2 (15\% increase in shear capacity when thickness of plate is increased from $4.8 \mathrm{~mm}$ to $11 \mathrm{~mm}$ compared to $8 \%$ for wall 3 and $6 \%$ for wall4) because of the placement of the steel plate out of the centerline of the wall and thus most sensitive among the other two composite walls to buckling. Hence, when the thickness of the plate is increased, the buckling resistance of the steel plate in the wall 2 increased more than the other walls. In wall 3 and wall4 which have sufficient steel plate resistance to the shear buckling, the change in the thickness of plate from $4.8 \mathrm{~mm}$ to $11 \mathrm{~mm}$ does not affect the shear capacity remarkably.

The increase in plate thickness is found to improve the energy dissipation capacity of the composite shear walls. This can be justified by examining the envelope curves

(b)

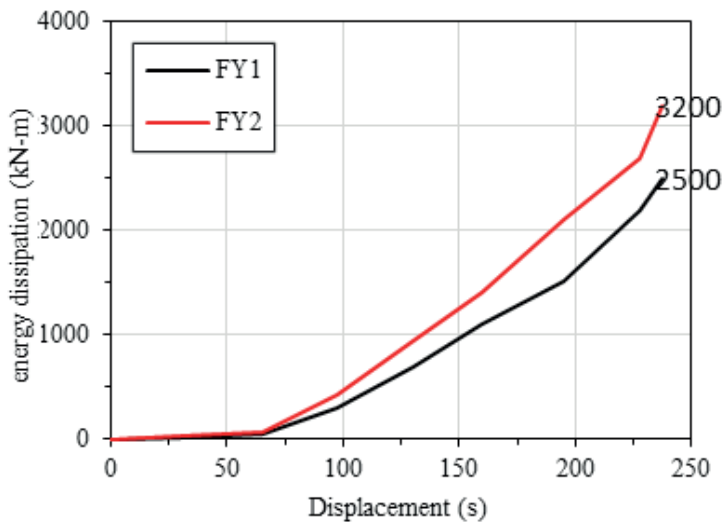

(c)

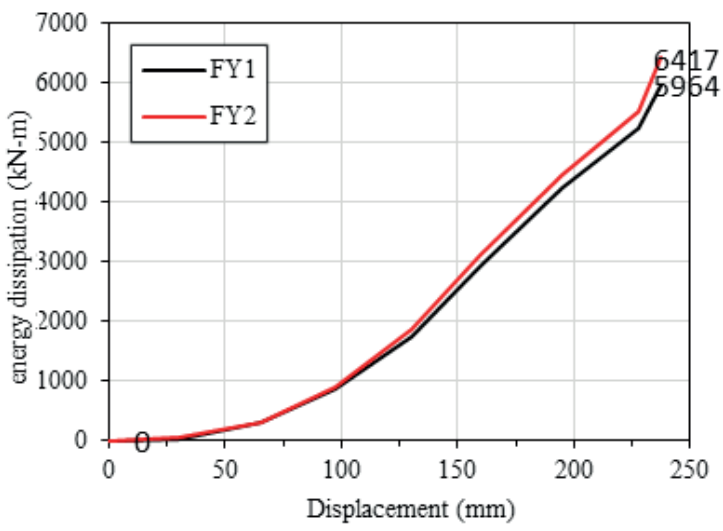

Fig. 14 Effect of yield strength of steel plate $(\mathrm{Fy} 1=370 \mathrm{MPa}, \mathrm{Fy} 2=520 \mathrm{MPa})$ on the skeleton curve of energy absorption of the shear walls 

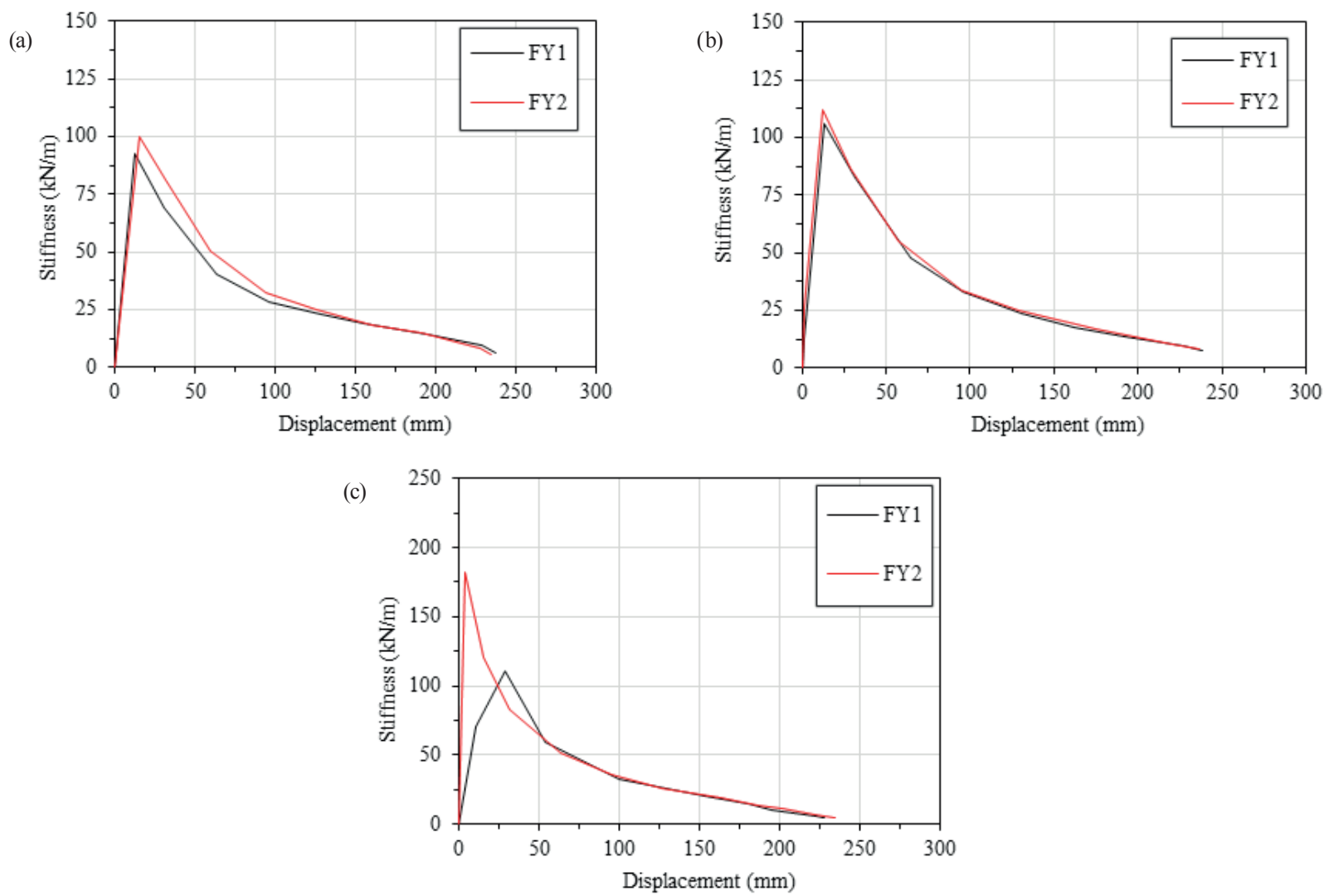

Fig. 15 Effect of yield strength of steel plate $(\mathrm{Fy} 1=370 \mathrm{MPa}, \mathrm{Fy} 2=520 \mathrm{MPa})$ on the skeleton curve of stiffness degradation of the shear walls
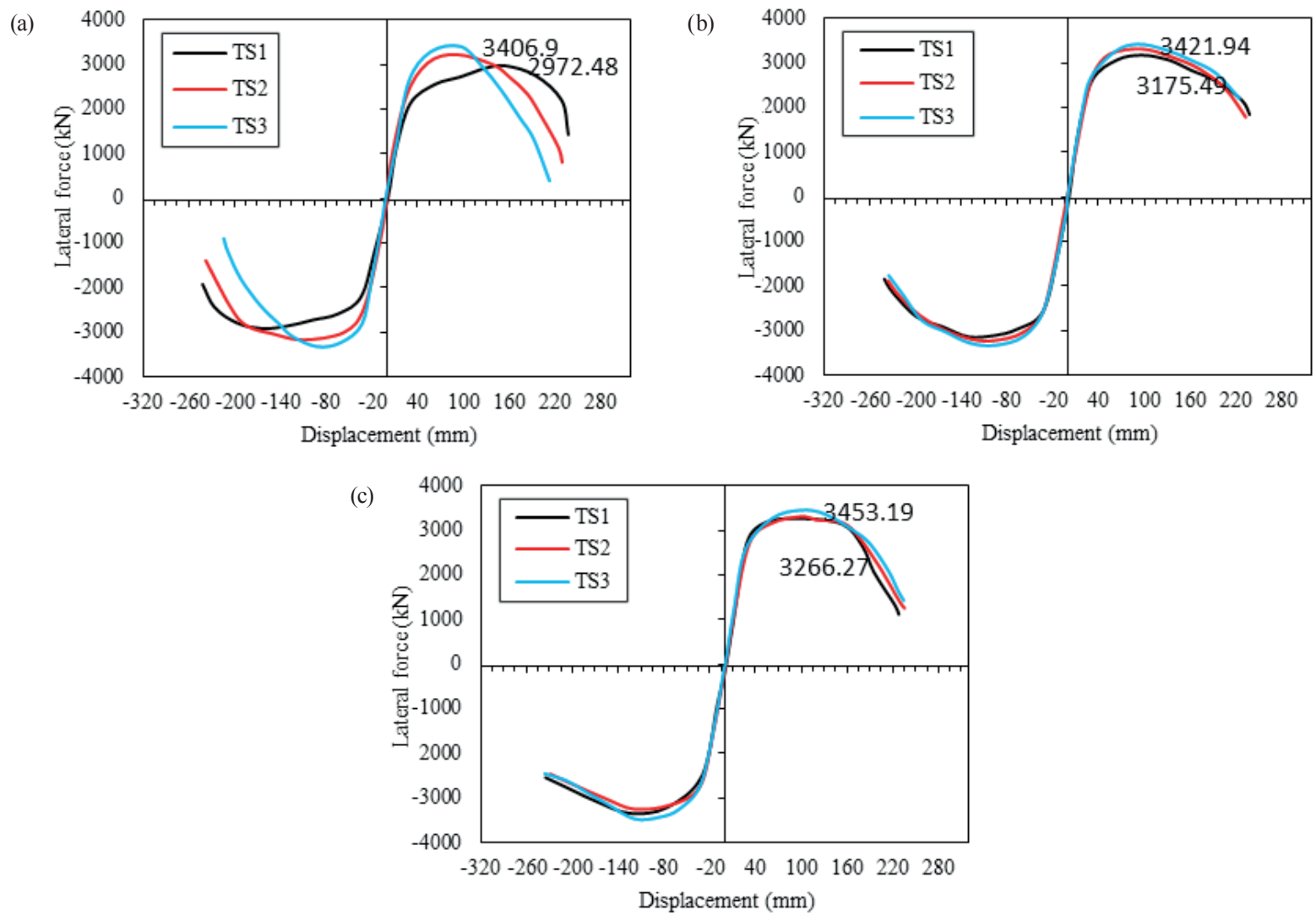

Fig. 16 Effect of steel plate thickness $(\mathrm{TS} 1=4.8, \mathrm{TS} 2=8, \mathrm{TS} 3=11 \mathrm{~mm})$ on the skeleton curve of shear capacity of the shear walls 
of the energy absorption provided in Fig. 17. It is interesting to note that the capacity of energy absorption of wall4 with the plate thickness of $11 \mathrm{~mm}$ is about 2.5 and 1.5 times greater than that of wall3 and wall2, respectively.

The plate thickness has the most remarkable effect on the stiffness of wall2 (Fig. 18). The initial stiffness of wall2 is increased from 90 to $200 \mathrm{kN} / \mathrm{m}$ when the thickness of the steel plate is increased from $4.8 \mathrm{~mm}$ to $11 \mathrm{~mm}$. It shows about $220 \%$ increase in the elastic stiffness of the wall2. In the wall3 and wall4, the increase of the plate thickness cannot improve the initial stiffness significantly. On the other hand, the largest reduction in the stiffness during the cyclic loading is also observed in wall 2 which has the greatest initial stiffness. It demonstrates that by increasing the plate thickness, the stiffness degradation is also increased.

\section{Comparison of the performances of the shear walls}

In this section, based on the results obtained from the parametric study, some comparisons between the performances of the shear walls are provided which can help in better understanding the seismic behaviors of composite shear walls. For the sake of brevity, the comparisons of the behavior of the shear walls with the height-to-length ratio equal to $1: 1$ only is presented.

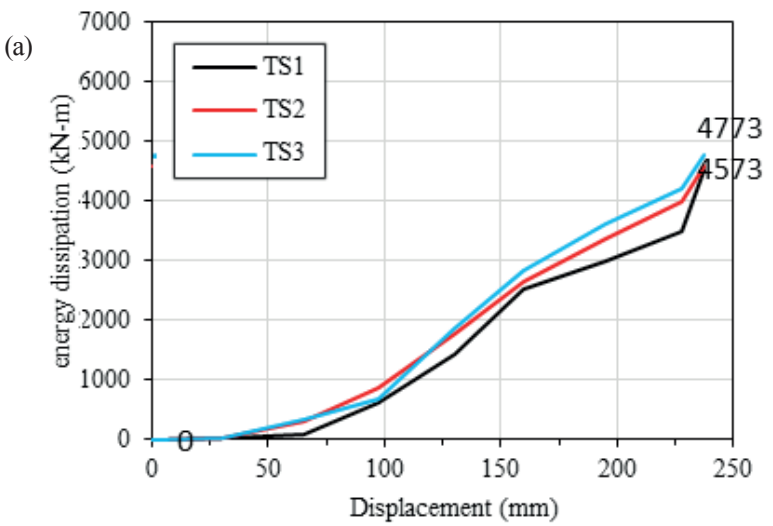

According to Figs. 19 and 20, it can be derived that the wall4 has exhibited the highest shear capacity among the other types of the composite shear walls followed by wall3 and wall2. As it is observed from these figures, all three types of the composite shear walls have a larger shear capacity than the conventional reinforced concrete shear wall.

As can be seen from Fig. 21, a similar order exists between the four types of the shear walls when they are compared with each other considering the capacity of the energy absorption. It is interesting to note that the wall2 (composite wall composed of a reinforced concrete panel connected to an external steel faceplate) has a similar energy absorption compared to the wall1. However, the wall3 and wall4 show a much better performance in energy dissipation than the RC shear wall. Wall4 represents a remarkable performance in energy absorption. Its capacity in dissipating energy is two times greater than that of the RC shear wall.

According to Fig. 22, it can be realized that again the wall4 has the largest lateral stiffness among the 4 types of the shear walls studied here. Furthermore, it can be deduced from this figure that the composite shear walls show the lower stiffness degradation than the RC shear wall during the increase of the cycles of the lateral loading.

(b)

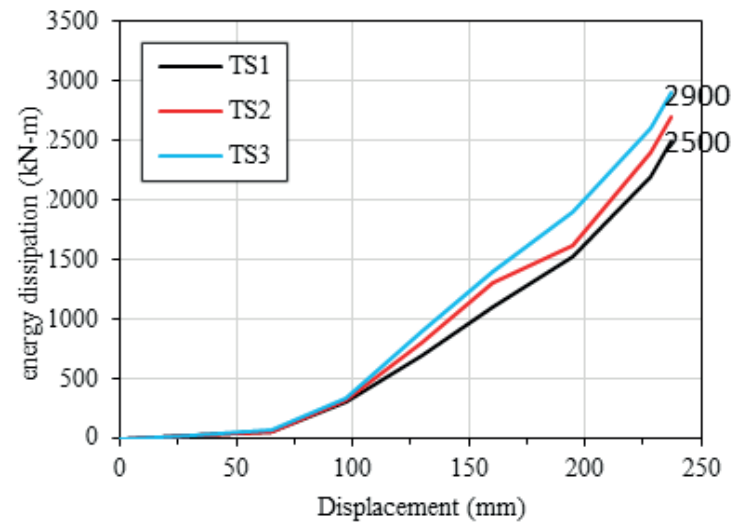

(c)

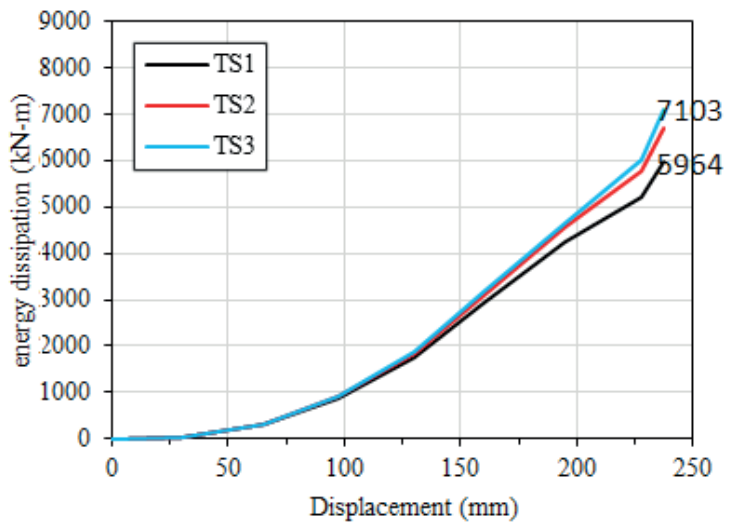

Fig. 17 Effect of plate thickness $(\mathrm{TS} 1=4.8, \mathrm{TS} 2=8, \mathrm{TS} 3=11 \mathrm{~mm})$ on the skeleton curve of energy dissipation of the shear walls 

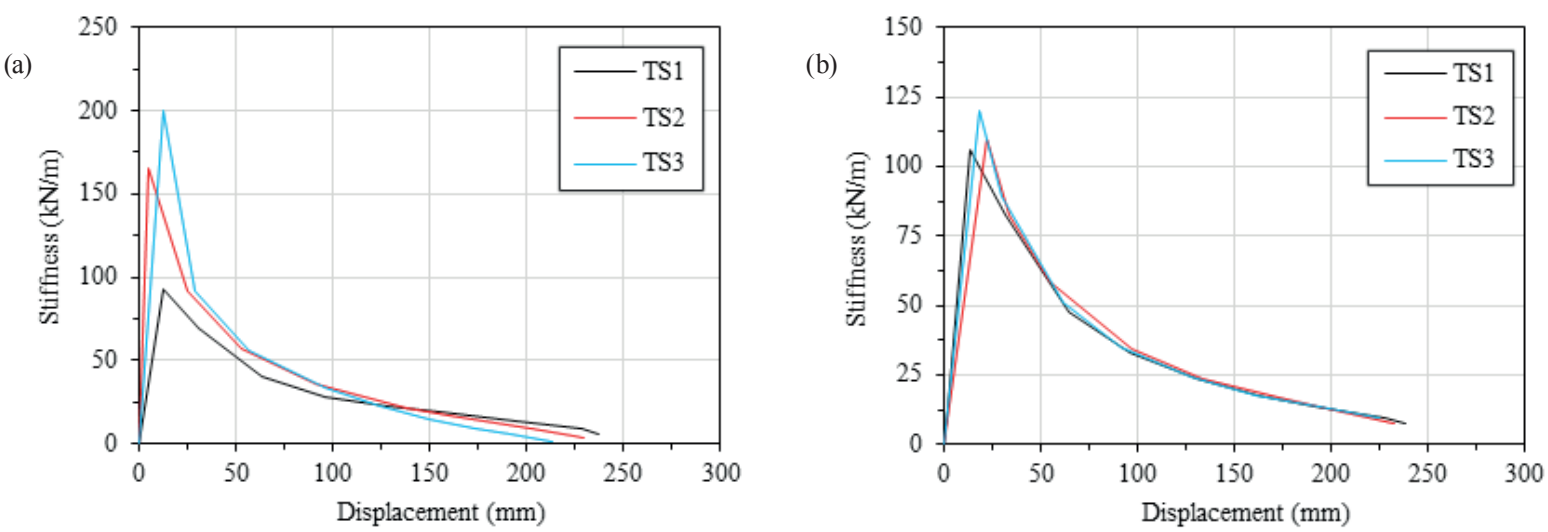

(c)

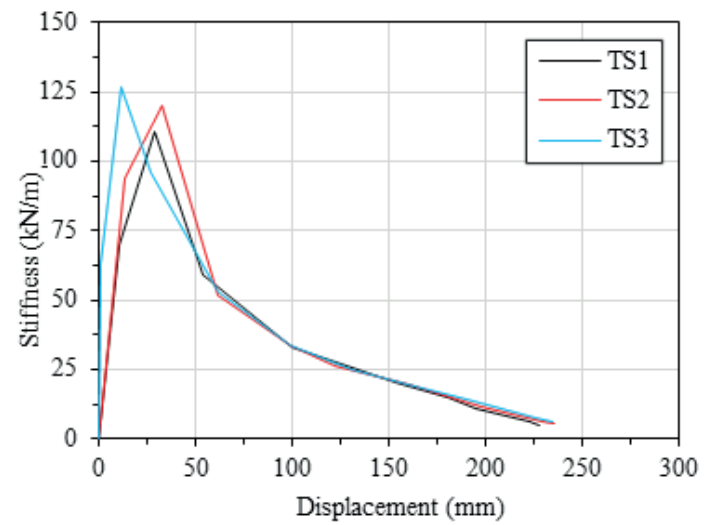

Fig. 18 Effect of plate thickness $(\mathrm{TS} 1=4.8, \mathrm{TS} 2=8, \mathrm{TS} 3=11 \mathrm{~mm}$ ) on the skeleton curve of stiffness degradation of the shear walls

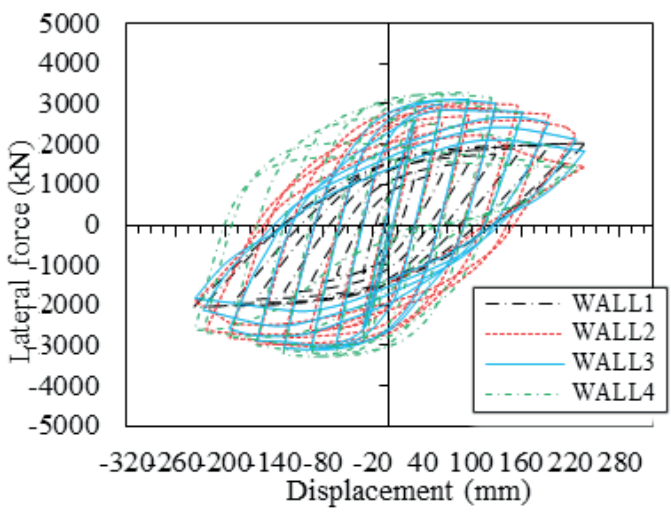

Fig. 19 Comparison of the hysteretic curves of the shear capacity of the composite shear walls

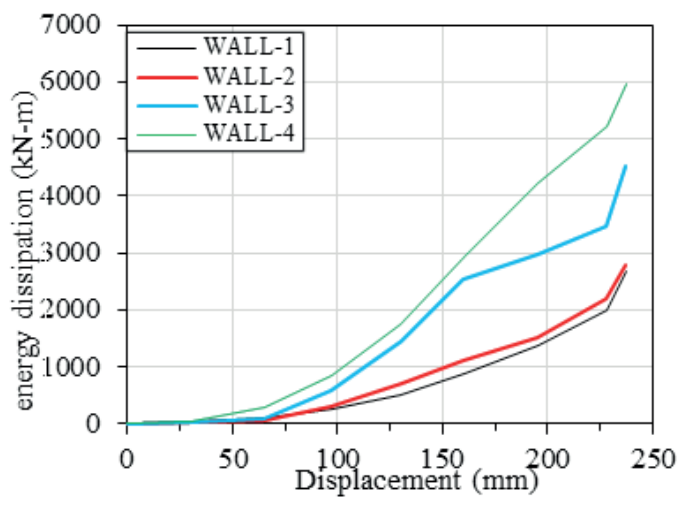

Fig. 21 Comparison of the skeleton curves of the energy dissipation of the composite shear walls

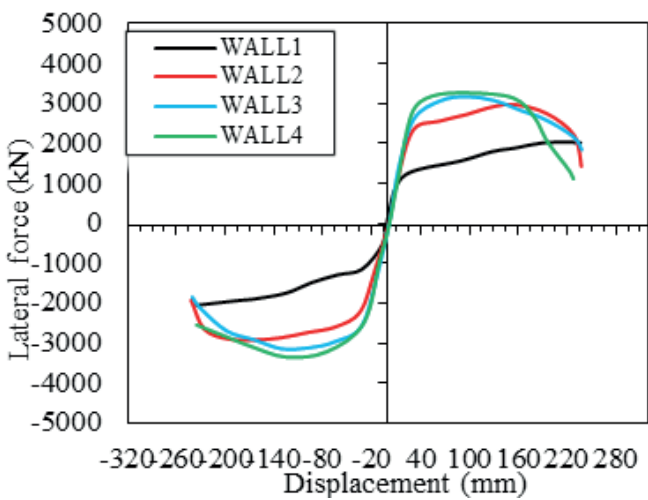

Fig. 20 Comparison of the skeleton curves of the shear capacity of the composite shear walls

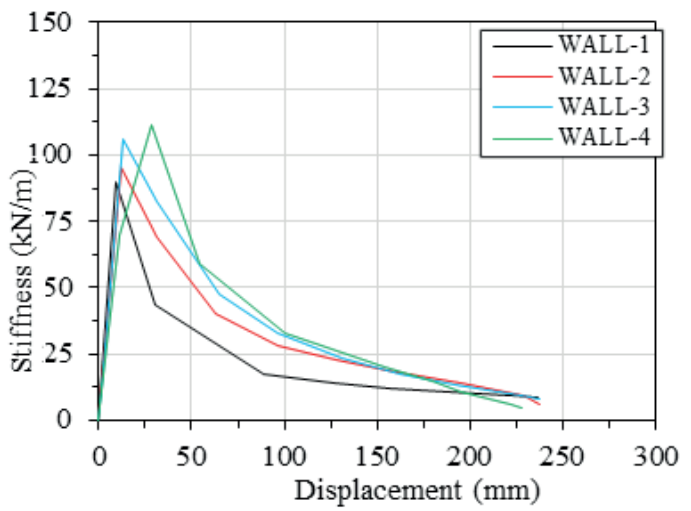

Fig. 22 Comparison of the skeleton curves of the stiffness degradation of the composite shear walls 
Fig. 23 illustrates the distribution of the von-Mises stresses within the four types of the shear walls at failure instant. All shear walls have the same compressive strength of concrete (30 MPa), height-to-length ratio (1:1.5), yield strength of steel plate $(360 \mathrm{MPa})$ and steel plate thickness $(4.8 \mathrm{~mm})$. This figure shows that in all the four walls, the boundary columns in the vicinity of the fix-end supports are fully yielded (with stress greater than $370 \mathrm{MPa}$ ) at the failure moment. Furthermore, it can be seen from this Fig. that the blue regions in infill panel of wall4 and wall3 are more than that of the wall 2 at the failure moment. This means that the level of stress in the walls 4 and 3 are lower than wall2. Hence, these walls can tolerate more loads before failure
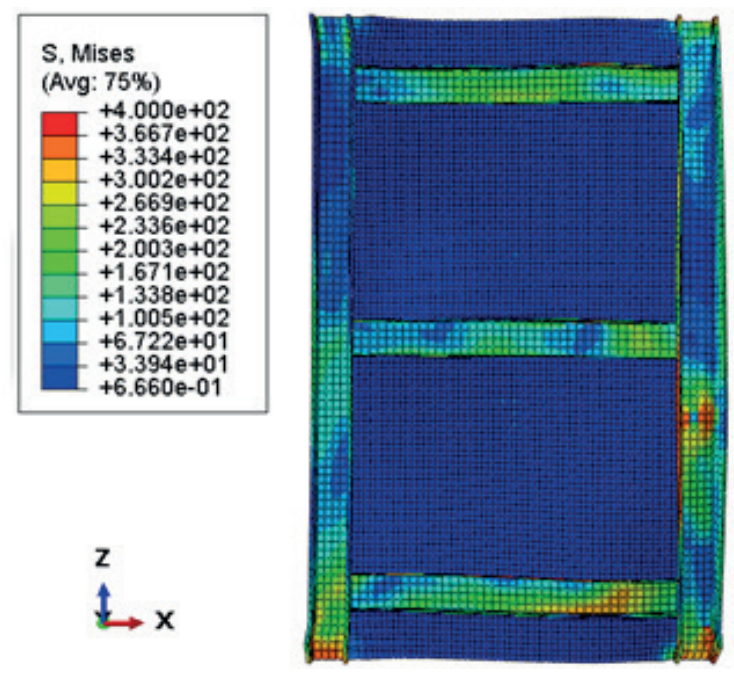

(a)
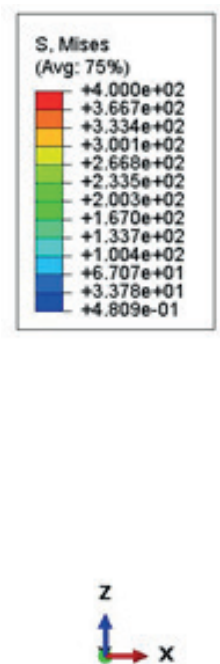

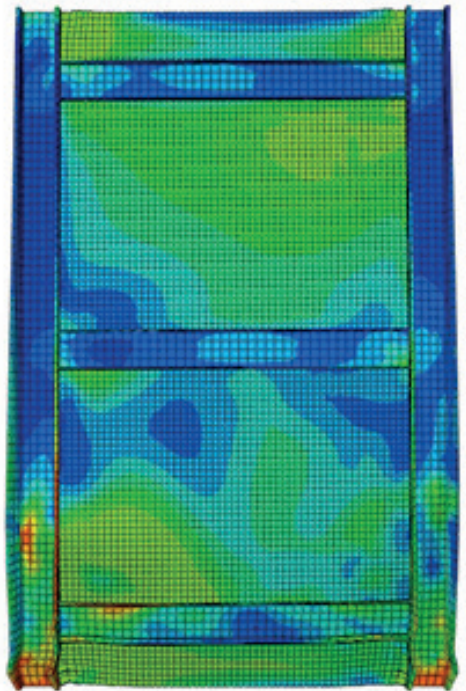

(c) and thus have greater shear capacity, stiffness, and energy absorption capacity than those of wall2. Fig. 24 illustrates the cracking and crushing of the concrete panel of the wall4 compared to the corresponding experimental sample. As it can be seen from this Fig. 24(a), the most regions of the concrete panel are of the grey color. This means that the plastic strain of the concrete in these parts is greater than the tensile and compressive limit strengths of the concrete and thus these regions are cracked or crushed at the failure stage. This observation is in agreement with the actual status of the wall in the experiment. As it is observed in Fig. 24(b), most parts of the concrete panel in the experimental sample are destroyed at the failure moment.
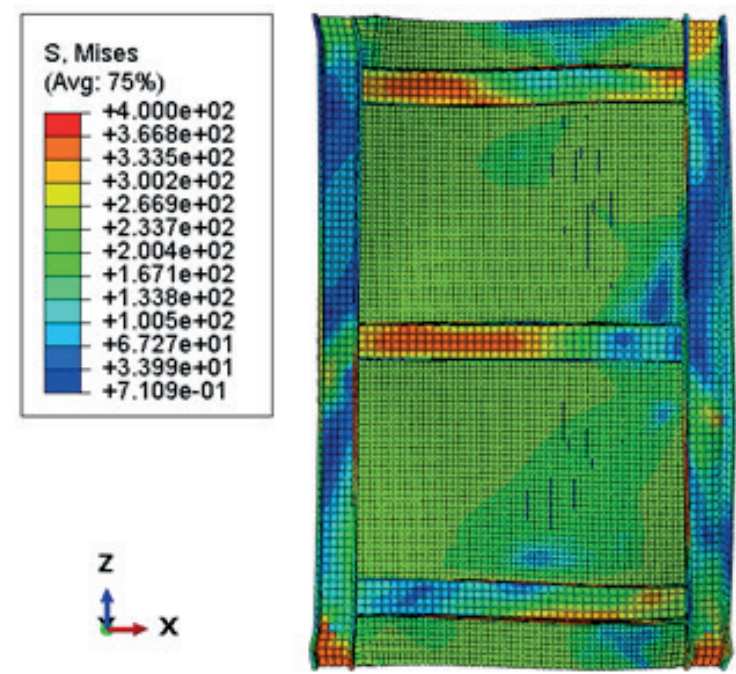

(b)
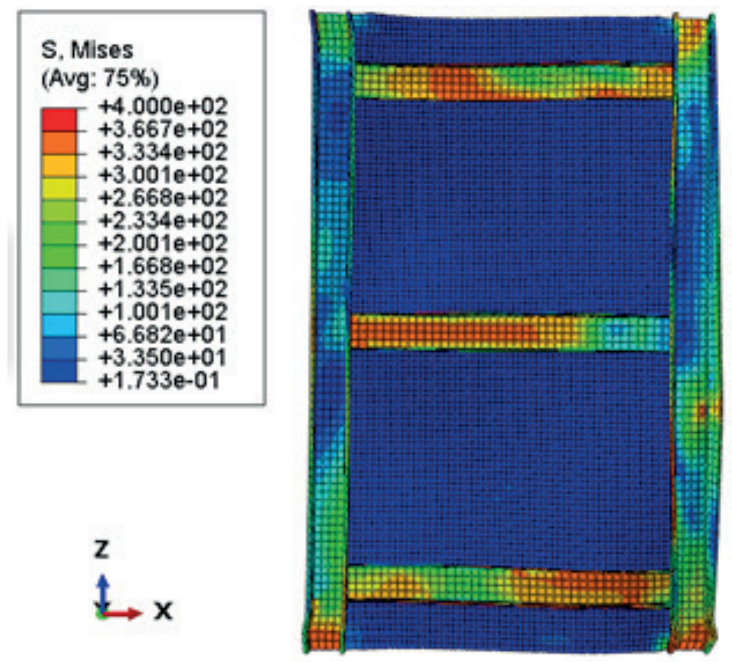

(d)

Fig. 23 Development of von-Mises stresses in the shear walls at failure instant 


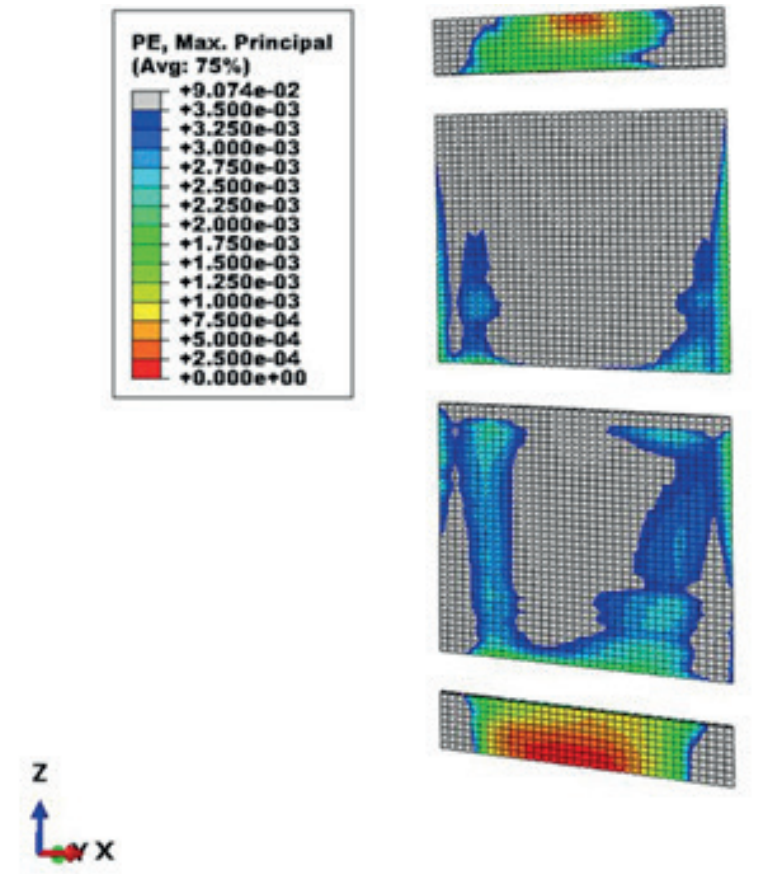

(a)

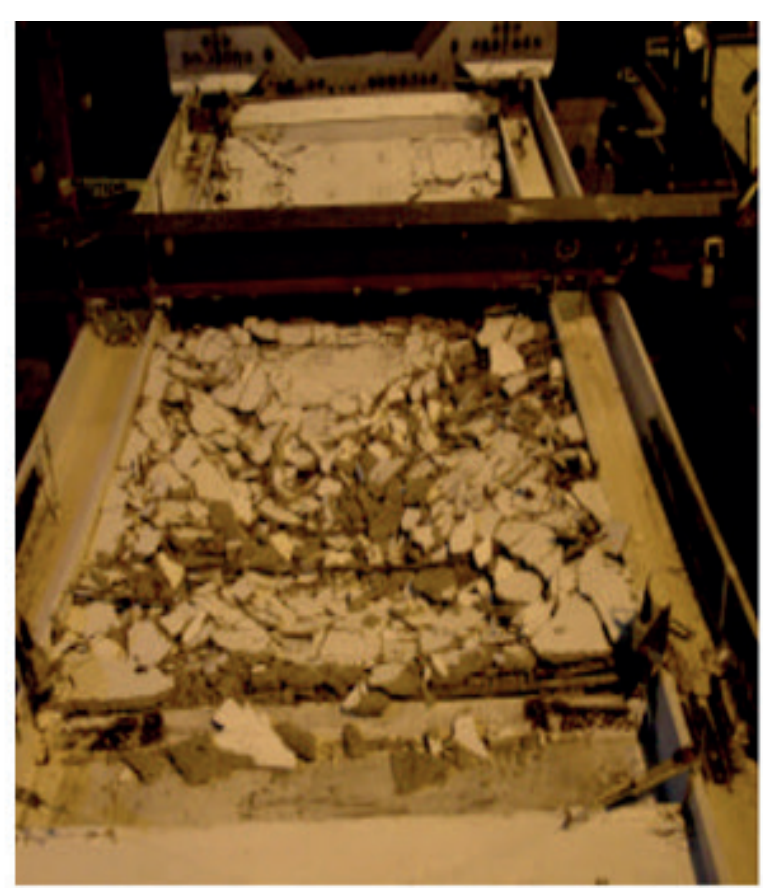

(b)

Fig. 24 Development of plastic strain in wall4 at the failure stage: (a) current study, (b) experiment

\section{Conclusions}

Based on the results and discussions represented in Sections 3 and 4 of this study, the following conclusions can be drawn:

Steel-concrete composite shear walls present more shear load capacity, energy absorption and shear stiffness under the effect of an in-plane lateral cyclic loading than a conventional RC shear wall. For instance, wall4 has exhibited about $52 \%$ increase in shear load capacity, $100 \%$ increase in energy absorption and 40\% increase in shear stiffness compared to traditional RC wall1.

Among the three types of the composite shear walls considered in this study, the wall4 presents the same shear load capacity as the wall3 and 10\% higher shear load capacity than that of wall2. Wall4 can absorb 33\% and $100 \%$ more strain energy than that of the wall 3 and wall2, respectively. This wall has a shear stiffness about $7 \%$ and $24 \%$ greater than that of the wall3 and wall2, respectively.

Increasing the compressive strength of concrete can improve the seismic performance of all the four types of shear walls, but has the most positive influence on the shear stiffness of the conventional RC shear wall and shows negligible effects on the behavior of the composite shear walls. Regarding the shear load capacity, the increase of the compressive strength of concrete from 30 to $60 \mathrm{MPa}$ can increase the shear strength of the wall1 from 2030 to $2350 \mathrm{kN}$ showing a $16 \%$ increase in shear load capacity. This increase for the wall2, wall 3 and wall4 are $8 \%, 5 \%$, and $2 \%$ accordingly. From the energy dissipation capacity point of view, the increase in concrete strength from 30 to $60 \mathrm{MPa}$ can increase the energy absorption of the wall1 near to $23 \%$. This increase for the walls 2 , 3 , and 4 are $3 \%$, $20 \%$, and $12 \%$, respectively. The promotion of the compressive strength from 30 to $60 \mathrm{MPa}$ can improve the shear stiffness of the wall1 up to $36 \%$ whereas this promotion can increase the shear stiffness of the walls 2,3 , and 4 about to $26 \%, 10 \%$, and $4 \%$, respectively.

Increasing the height-to-length ratio of the all 4 types of the shear walls indicates negative effects on the seismic performance of them. In contrast, decreasing this ratio can improve the performance. Decreasing the height-to-length ratio from 3:1 to 1:1.5 can improve the shear strength of the walls $1,2,3$, and 4 about to $91 \%, 164 \%, 171 \%$, and $187 \%$ respectively. Similar reduction in height-to-length ratio can increase the energy absorption capacity of the walls $1,2,3$, and 4 about to $63 \%, 164 \%, 400 \%$, and $173 \%$ respectively. The same reduction in height-to-length ratio can increase the shear stiffness of the walls $1,2,3$, and 4 near to $900 \%$, $558 \%, 455 \%$, and $584 \%$, respectively.

Enlargement the yield strength of the steel plate has totally a little effect on the performance of the composite shear walls with an exception for the wall4 in which the shear stiffness of the wall can improve significantly by increasing the yield strength of the steel plate. With increasing the yield strength of the steel plate from 370 to $520 \mathrm{MPa}$, the 
shear load capacity of the walls 2, 3, and 4 increases $6.5 \%$, $1.6 \%$, and 3\% respectively. Such an increase can improve the energy absorption capacity of the walls 2,3 , and 4 near to $34 \%, 28 \%$, and $7 \%$ accordingly. The shear stiffness of the walls 2,3 , and 4 increases by $8 \%, 5 \%$ and $64 \%$ respectively when such an increase occurs in the plate thickness.

Increasing the plate thickness exhibits the most improvement in the shear stiffness of the wall2. The effects of this parameter on the behavior of other functions of the shear walls can be neglected. When the thickness of the steel plate increases from $4.8 \mathrm{~mm}$ to $11 \mathrm{~mm}$, the shear strength of the walls 2,3 , and 4 increases $14 \%, 16 \%$, and $6 \%$ respectively.

\begin{tabular}{|c|c|}
\hline $\begin{array}{l}\text { List of } \\
\text { Abreviations }\end{array}$ & HL1 \\
\hline $\mathrm{FE}$ & Finite Element \\
\hline $\mathrm{RC}$ & Reinforced Concrete \\
\hline Wall1 & $\mathrm{RC}$ shear wall \\
\hline Wall2 & $\begin{array}{l}\text { A composite shear wall composed of a single external } \\
\text { steel plate connected to a concrete panel }\end{array}$ \\
\hline Wall3 & $\begin{array}{l}\text { A composite shear wall constructed from two external } \\
\text { steel plates connected to an internal concrete panel }\end{array}$ \\
\hline Wall4 & $\begin{array}{l}\text { A composite shear wall fabricated with a single } \\
\text { internal steel plate embedded within a concrete panel }\end{array}$ \\
\hline DSCSW & $\begin{array}{l}\text { Double skin profiled steel concrete composite shear } \\
\text { wall }\end{array}$ \\
\hline CSPSW & Concrete stiffened steel plate composite shear wall \\
\hline CPSW & Composite steel plate shear wall \\
\hline CDP & Concrete Damage Plasticity model \\
\hline$F_{v}$ & Yield stress of steel \\
\hline Fy1 & Steel with yield stress of $360 \mathrm{MPa}$ \\
\hline Fy2 & Steel with yield stress of $520 \mathrm{MPa}$ \\
\hline $\mathrm{Fcl}$ & Concrete with strength of $30 \mathrm{MPa}$ \\
\hline $\mathrm{Fc} 2$ & Concrete with strength of $60 \mathrm{MPa}$ \\
\hline
\end{tabular}

\section{References}

[1] Jiang, L., Ye, J. "Redundancy of a mid-rise CFS composite shear wall building based on seismic response sensitivity analysis", Engineering Structures, 200, Article number: 19647, 2019. https://doi.org/10.1016/j.engstruct.2019.109647

[2] Wang, W., Song, J., Hou, M., Liu, G., Wang, W. "Experimental study and numerical simulation of replaceable corrugated steel plate-concrete composite shear walls", Soil Dynamics and Earthquake Engineering, 127, Article number: 105827, 2019. https://doi.org/10.1016/j.soildyn.2019.105827

[3] Haghi, N., Epackachi, S., Kazemi, M. T. "Macro modeling of steelconcrete composite shear walls", Structures, 23, pp. 383-406, 2020. https://doi.org/10.1016/j.istruc.2019.10.018

[4] Guo, L., Wang, Y., Zhang, S. "Experimental study of rectangular multi-partition steel-concrete composite shear walls", Thin-Walled Structures, 130, pp. 577-592, 2018. https://doi.org/10.1016/j.tws.2018.06.011
Under the effect of such an increase in the plate thickness, the energy absorption of the walls 2,3 , and 4 increases $4 \%$, $16 \%$, and $19 \%$ respectively. The shear stiffness of the walls 2,3 , and 4 increases by $117 \%, 13 \%$, and $6 \%$ respectively when the plate thickness increases from $4.8 \mathrm{~mm}$ to $11 \mathrm{~mm}$.

According to the above-mentioned conclusions, it is evident that among the 4 parameters including the compressive strength of concrete, height-to-length ratio, yield strength of the steel plate and finally the thickness of the steel plate, reduction of the height-to-length ratio has the most positive effects on the seismic performance of the all 4 types of the shear walls.

\begin{tabular}{ll}
\hline $\begin{array}{l}\text { Height-to-length } \\
\text { ratio equal to } 1\end{array}$ \\
\hline HL2 & Height-to-length ratio equal to 0.67 \\
HL3 & Height-to-length ratio equal to 2 \\
HL4 & Height-to-length ratio equal to 3 \\
TS1 & Plate thickness equal to $4.8 \mathrm{~mm}$ \\
TS2 & Plate thickness equal to $8 \mathrm{~mm}$ \\
TS3 & Plate thickness equal to $11 \mathrm{~mm}$ \\
$\mathrm{E}$ & Modulus of Elasticity \\
$f_{c}$ & Concrete compressive strength \\
$\varnothing$ & Dilation angle in CDP model \\
$e$ & Eccentricity in CDP model \\
$f_{b 0} / f_{c 0}$ & $\begin{array}{l}\text { Biaxial-to-uniaxial compressive strength of } \\
\text { concrete in CDP model }\end{array}$ \\
$k_{c}$ & $\begin{array}{l}\text { Ratio of distance of compressive to tensile } \\
\text { meridians from hydrostatic axis }\end{array}$ \\
& Viscosity in CDP model \\
& Density of concrete \\
& Poisson's ratio of concrete \\
\hline
\end{tabular}

[5] Zhao, Q., Astaneh-Asl, A. "Cyclic Behavior of Traditional and Innovative Composite Shear Walls", Journal of Structural Engineering, 130(2), pp. 271-284, 2004.

https://doi.org/10.1061/(ASCE)0733-9445(2004)130:2(271)

[6] Hossain, K. M. A., Wright, H. D. "Behavior of composite walls under monotonic and cyclic shear Loading", Structural Engineering and Mechanics, 17(1), pp. 69-85, 2004.

https://doi.org/10.12989/sem.2004.17.1.069

[7] Rafiei, S., Hossain, K. M. A., Lachemi, M., Behdinan, K., Anwar, M. S. "Finite element modeling of double skin profiled composite shear wall system under in-plane loadings", Engineering Structures, 56, pp. 46-57, 2013

https://doi.org/10.1016/j.engstruct.2013.04.014

[8] Hossain, K. M. A., Rafiei, S., Lachemi, M., Behdinan, K. "Structural performance of profiled composite wall under in-plane cyclic loading", Engineering Structures, 110, pp. 88-104, 2016. https://doi.org/10.1016/j.engstruct.2015.11.057 
[9] Rassouli, B., Shafaei, S., Ayazi, A., Farahbod, F. "Experimental and numerical study on steel-concrete composite shear wall using lightweight concrete", Journal of Constructional Steel Research, 126, pp. 117-128, 2016. https://doi.org/10.1016/j.jcsr.2016.07.016

[10] Zhao, W., Guo, Q., Huang, Z., Tan, L., Chen, J., Ye, Y. "Hysteretic model for steel-concrete composite shear walls subjected to in-plane cyclic loading", Engineering Structures, 106, pp. 461-470, 2016. https://doi.org/10.1016/j.engstruct.2015.10.031

[11] Wang, W., Wang, Y., Lu, Z. "Experimental study on seismic behavior of steel plate reinforced concrete composite shear wall", Engineering Structures, 160, pp. 281-292, 2018. https://doi.org/10.1016/j.engstruct.2018.01.050

[12] Zhang, W., Wang, K., Chen, Y., Ding, Y. "Experimental study on the seismic behavior of composite shear walls with stiffened steel plates and infilled concrete", Thin-Walled Structures, 144, Article number: 106279, 2019.

https://doi.org/10.1016/j.tws.2019.106279

[13] Wang, W., Ren, Y., Lu, Z., Song, J., Han, B., Zhou, Y. "Experimental study of the hysteretic behavior of corrugated steel plate shear walls and steel plate reinforced concrete composite shear walls", Journal of Constructional Steel Research, 160, pp. 136-152, 2019. https://doi.org/10.1016/j.jcsr.2019.05.019

[14] Booth, P. N., Bhardwaj, S. R., Tseng, T.-C., Seo, J., Varma, A. H. "Ultimate shear strength of steel-plate composite (SC) walls with boundary elements", Journal of Constructional Steel Research, 165, Article number: 105810, 2020.

https://doi.org/10.1016/j.jcsr.2019.105810

[15] Nie, X., Wang, J.-J., Tao, M.-X., Fan, J.-S., Bu, F.-M. "Experimental study of flexural critical reinforced concrete filled composite plate shear walls", Engineering Structures, 197, Article number: 109439, 2019.

https://doi.org/10.1016/j.engstruct.2019.109439

[16] Labibzadeh, M., Jamalpour, R., Jing, D. H., Khajehdezfuly, A. "A Numerical Comparison between Spiral Transverse RC and CFST Columns under Loads of Varying Eccentricities", Periodica Polytechnica Civil Engineering, 63(4), pp. 1171-1182, 2019. https://doi.org/10.3311/PPci.14177

[17] Gholipour, M., Alinia, M. M. "Considerations on the Pushover Analysis of Multi-Story Steel Plate Shear Wall Structures", Periodica Polytechnica Civil Engineering, 60(1), pp. 113-126, 2016. https://doi.org/10.3311/PPci.7706

[18] Raza, A., Zaman Khan, Q., Ahmad, A. "Numerical Investigation of Load-Carrying Capacity of GFRP-Reinforced Rectangular Concrete Members Using CDP Model in ABAQUS", Advances in Civil Engineering, 2019, Article ID 1745341, 2019.

https://oi.org/10.1155/2019/1745341

[19] Mehmood, T., Maqsoom, A., Nawaz, A., Zeeshan, B.-U. A. "Experimental and Numerical Seismic Evaluation of RC Walls Under Axial Compression", Periodica Polytechnica Civil Engineering, 64(1), pp. 122-137, 2020.

https://doi.org/10.3311/PPci.14333
[20] Raza, A., Zaman Khan, Q., Ahmad, A. "Investigation of HFRC Columns Reinforced with GFRP Bars and Spirals under Concentric and Eccentric Loadings", Engineering Structures, 227, Article number: $111461,2021$. https://doi.org/10.1016/j.engstruct.2020.111461

[21] Tahir, M. F., Shabbir, F., Ahmad, A., Ejaz, N. "Experimental and Numerical Investigation of Transverse Circular Holes on LoadCarrying Capacity of RC Columns", Iranian Journal of Science and Technology, 45, pp. 683-696, 2021. https://doi.org/10.1007/s40996-020-00372-2

[22] Chaouch, A .A., Boutemeur, R., Bechtoula, H., Bali, A. "Numerical Study on Shear Stress Variation of RC Wall with L Shaped Section", Periodica Polytechnica Civil Engineering, 59(1), pp. 15-25, 2015. https://doi.org/10.3311/PPci.7575

[23] Ahmad, A., Zaman Khan, Q., Raza, A. "Reliability Analysis of Strength Models for CFRP-Confined Concrete Cylinders", Composite Structures, 25(5), Article number: 112312, 2020. https://doi.org/10.1016/j.compstruct.2020.112312

[24] Mustafaraj, E., Yardim, Y. "In-plane Shear Strengthening of Unreinforced Masonry Walls Using GFRP Jacketing", Periodica Polytechnica Civil Engineering, 62(2), pp. 330-336, 2018. https://doi.org/10.3311/PPci.11311

[25] Lee, J., Fenves, G. L. "Plastic-Damage Model for Cyclic Loading of Concrete Structures", Journal of Engineering Mechanics, 124(8), pp. 892-900, 1998. https://doi.org/10.1061/(ASCE)0733-9399(1998)124:8(892)

[26] Lubliner, J., Oliver, J., Oller, S., Oñate, E. "A plastic-damage model for concrete", International Journal of Solids Structures, 25(3), pp. 299-326, 1989. https://doi.org/10.1016/0020-7683(89)90050-4

[27] Labibzadeh, M., Hamidi, R. "A Design Formula for Lateral Load Resistance of Concrete Filled Double-Steel-Plate Walls with Small Height-to-Length Ratio", KSCE Journal of Civil Engineering, 23, pp. 3493-3508, 2019.

https://doi.org/10.1007/s12205-019-1588-7

[28] Labibzadeh, M., Zakeri, M., Shoaib, A. A. "A new method for CDP input parameter identification of the ABAQUS software guaranteeing the uniqueness and precision", International Journal of Structural Integrity, 8(2), pp. 264-284, 2017. https://doi.org/10.1108/IJSI-03-2016-0010

[29] Hossain, K. M. A. "Properties of volcanic pumice based cement and lightweight concrete", Cement and Concrete Research, 34(2), pp. 283-291, 2004. https://doi.org/10.1016/j.cemconres.2003.08.004

[30] Lachemi, M., Hossain, K. M. A., Lambros, V., Nkinamubanzi, P.-C., Bouzoubaâ, N. "Self-consolidating concrete incorporating new viscosity modifying admixtures", Cement and Concrete Research, 34(6), pp. 917-926, 2004.

https://doi.org/10.1016/j.cemconres.2003.10.024

[31] Hossain, K. M. A. "High strength blended cement concrete incorporating volcanic ash: Performance at high temperatures", Cement and Concrete Research, 28(6), pp. 535-545, 2006. https://doi.org/10.1016/j.cemconcomp.2006.01.013 